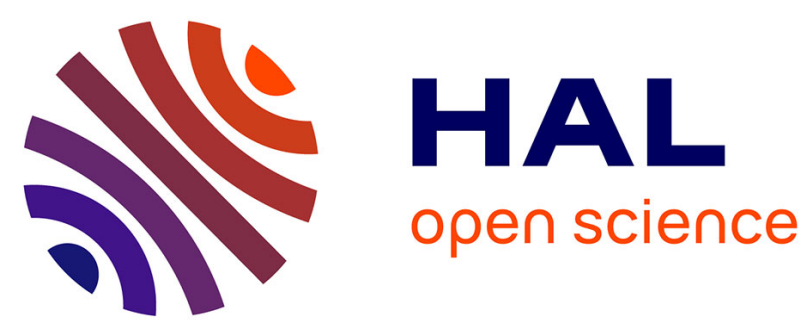

\title{
Environmental and demographic factors influence the spatial genetic structure of an intertidal barnacle in central-northern Chile
}

Mario Barahona, Bernardo R Broitman, Sylvain Faugeron, Lucie Jaugeon, A Ospina-Alvarez, David Véliz, Sergio A Navarrete

\section{To cite this version:}

Mario Barahona, Bernardo R Broitman, Sylvain Faugeron, Lucie Jaugeon, A Ospina-Alvarez, et al.. Environmental and demographic factors influence the spatial genetic structure of an intertidal barnacle in central-northern Chile. Marine Ecology Progress Series, 2019, 612, pp.151-165. 10.3354/meps12855. hal-02064081

\section{HAL Id: hal-02064081 \\ https://hal.sorbonne-universite.fr/hal-02064081}

Submitted on 11 Mar 2019

HAL is a multi-disciplinary open access archive for the deposit and dissemination of scientific research documents, whether they are published or not. The documents may come from teaching and research institutions in France or abroad, or from public or private research centers.
L'archive ouverte pluridisciplinaire HAL, est destinée au dépôt et à la diffusion de documents scientifiques de niveau recherche, publiés ou non, émanant des établissements d'enseignement et de recherche français ou étrangers, des laboratoires publics ou privés. 


\section{Environmental and demographic factors influence the spatial genetic structure of an intertidal barnacle in central-northern Chile}

4

\section{Mario Barahona ${ }^{1,2}$, Bernardo R. Broitman ${ }^{3,4}$, Sylvain Faugeron ${ }^{2,5, *}$, Lucie Jaugeon ${ }^{5}$, Andrés} Ospina-Alvarez ${ }^{6}$, David Véliz ${ }^{7}$, Sergio A. Navarrete ${ }^{1,8}$

${ }^{1}$ Estación Costera de Investigaciones Marinas - Las Cruces, Facultad de Ciencias Biológicas, Pontificia Universidad Católica de Chile, El Tabo 2690931, Chile

${ }^{2}$ Departamento de Ecología, Facultad de Ciencias Biológicas, Pontificia Universidad Católica de Chile, Santiago 8331150, Chile

${ }^{3}$ Centro de Estudios Avanzados en Zonas Áridas, Universidad Católica del Norte, Coquimbo 1781421, Chile

${ }^{4}$ Departamento de Biología Marina, Facultad de Ciencias del Mar, Universidad Católica del Norte, Coquimbo 1781421, Chile

${ }^{5}$ CNRS, Sorbonne Université, Pontificia Universidad Católica de Chile, Universidad Austral de Chile, UMI Evolutionary Biology and Ecology of Algae, Station Biologique de Roscoff, 29680 Roscoff, France

${ }^{6}$ Mediterranean Institute for Advanced Studies (IMEDEA-CSIC/UIB), C/Miguel Marques 21, CP 07190 Esporles, Balearic Islands, Spain

${ }^{7}$ Departamento de Ciencias Ecológicas, Instituto de Ecología y Biodiversidad (IEB), Nucleo Milenio de Ecología y Manejo Sustentable de Islas Oceánicas (ESMOI), Universidad de Chile, Santiago 7800003, Chile

${ }^{8}$ Center for Applied Ecology and Sustainability (CAPES) and LINCGlobal, Pontificia Universidad Católica de Chile, Chile

RPH: Barahona et al.: Genetic structure of intertidal barnacles

*Corresponding author: sfaugeron@bio.puc.cl

ABSTRACT: Understanding the multiplicity of processes producing genetic patterns in natural populations can shed light on the ecology and evolution of species, and help guide effective management and conservation strategies. Here we investigated the role of environmental, demographic, and geographic factors in shaping the spatial patterns of genetic diversity and differentiation of the intertidal barnacle Notochthamalus scabrosus along the central-northern coast of Chile $\left(28-34^{\circ} \mathrm{S}\right)$. We analyzed genetic data from 7 microsatellite loci genotyped for 300 individuals sampled from 10 sites and combined this 
information with 8 site-specific environmental (4), demographic (2), and geographic (2) variables using least squares linear regressions, generalized linear models, and matrix regression analyses. We found a strong association between the spatially structured genetic diversity of $N$. scabrosus and patterns of temporal variability in chlorophyll $a$, and amongsite differences in seawater temperature and adult abundance, which in turn was related to overall recruitment levels. Our results illustrate that population size, partly driven by recruitment success, can leave a signal on genetic structure of this highly dispersive marine species. The significant effect of temperature and chlorophyll $a$ stresses that local adaptation may be key to understanding the spatial genetic structure of our model species. Hence, the results of this work represent an advance towards understanding the usually complex causal relationships between environmental variables, gene flow, and genetic diversity patterns of coastal populations.

KEY WORDS: Notochthamalus scabrosus · Seascape genetics · Larval dispersal · Coastal oceanography $\cdot$ Marine connectivity

\section{INTRODUCTION}

Population genetic diversity is important for a range of ecological and evolutionary processes. For example, genetic diversity can determine community structure and primary productivity (Crutsinger et al. 2006). It can be associated with the population growth rate of species (Hughes et al. 2008), and it allows species to adapt to changing environments and fosters persistence over evolutionary time scales (Reed \& Frankham 2003). Therefore, a strong scientific understanding of the processes that influence spatial genetic variation, genetic diversity, and population structure in nature is of paramount importance to implement efficient conservation and management strategies.

In marine systems, an early paradigm assumed that most organisms were highly dispersive and presented large population sizes, and thus were able to resist genetic divergence at all but perhaps the largest spatial scales. This overly simplistic view was gradually replaced by an increased understanding of hydrographic heterogeneity in the coastal ocean and the advent of molecular genetics, which unveiled many potential causes for genetic structure and speciation in organisms with large dispersal potential (Hellberg 2009, Selkoe et al. 2016). For example, due to the dependence of genetic diversity on population effective size (Ellegren \& Galtier 2016), demographic changes along the geographic range of a species can leave a discernible footprint in its spatial genetic makeup. Also, a realistic oceanic environment, especially when there is strong topographic modulation, presents ample opportunities for variation and restriction in effective dispersal distances (Largier 2003, Pringle et al. 2011, Nickols et al. 2015). Geographic distance per se imposes a distance limitation to gene flow, driving increased genetic differentiation with increasing distance between populations, a pattern known as isolation by distance (Wright 1943). Besides the limitation imposed by dispersal between distant populations, phenotype-environment mismatches can impose biological barriers to gene flow (Nosil et al. 2005), producing an isolation by environment, where populations with greater environmental dissimilarity exhibit higher levels of genetic differentiation, blurring or reinforcing patterns generated by geographic distance alone (Wang \& Bradburg 2014).

High-resolution molecular and environmental data are now routinely used to assess the influence of landscape-scale environmental characteristics on genetic variation and 
spatial patterns in natural populations of species. Altogether, the mounting evidence suggests that considerable genetic structure occurs in marine populations around areas where environmental oceanographic factors exhibit strong spatial structure or geographic discontinuity.

The central-northern coast of Chile represents an interesting study system to evaluate the effects of environmental, demographic and geographic factors on genetic diversity and differentiation of marine organisms. Superimposed on what are smooth latitudinal trends in mean sea surface temperature (SST) along this highly productive upwelling ecosystem, there is a marked change in oceanographic regimes that takes place around $30^{\circ} \mathrm{S}$. Such geographic discontinuity entails changes in upwelling-driven coastal circulation (Hormazabal et al. 2004, Aiken et al. 2011, Aguirre et al. 2014), as well as prevailing hydrographic conditions, such as SST variability, surface chlorophyll, and nutrient availability (Navarrete et al. 2005, Tapia et al. 2014). Coincidentally, at this same latitude, several studies have reported the occurrence of geographic distribution endpoints of several intertidal and subtidal invertebrate species (Lancellotti \& Vasquez 1999, Camus 2001), phylogeographic breaks of several invertebrates and macroalgae (Tellier et al. 2009, Haye et al. 2014), and large changes in population dynamics and abundance of dominant rocky shore species that otherwise extend far beyond this region (Broitman et al. 2001, Navarrete et al. 2005, 2008).

The geographic range of the intertidal barnacle Notochthamalus scabrosus (Darwin 1854) spans the $30^{\circ} \mathrm{S}$ transition zone, and its complete larval development to settlement takes well over $1 \mathrm{mo}$ at the water temperatures typically encountered in central Chile (Venegas et al. 2000). At the same time, the advective nature of coastal flow along central Chile (Aiken et al. 2007) sets the stage for a comparatively high potential for larval dispersal and genetic flow among distant populations of this species, as shown by biophysical models for other long-distance dispersers in the region (Garavelli et al. 2014). Moreover, large variation in larval arrival rates and adult cover have been reported for the central-northern coast, which has been attributed to differences in the temporal regime of upwelling-favorable winds (Navarrete et al. 2005, Lagos et al. 2008). A phylogenetic break in the $N$. scabrosus mitochondrial cytochrome oxidase I gene (mtCOI) around $30^{\circ} \mathrm{S}$ was reported by Zakas et al. (2009). Although spatially stable, there are significant temporal changes in gene frequencies near the break $\left(<30^{\circ} 55^{\prime} \mathrm{S}\right)$, presumably related to source-sink dynamics and/or low effective population sizes in this zone (Laughlin et al. 2012). Based on a large-scale circulation model, Ewers-Saucedo et al. (2016) suggested that the genetic break of $N$. scabrosus around $30^{\circ} \mathrm{S}$ requires differential performance of mtCOI lineages along the coast; in other words, it could not be maintained by dispersal limitation alone. Therefore, the diversity and genetic structure of $N$. scabrosus may respond to multiple causes, such as phylogeography, demography, geographical isolation, and selection pressures driven by environmental variation along the coastline.

This study takes advantage of the genetic information gathered for N. scabrosus, based on mtCOI, as well as of a long-term database (5-13 yr) of monthly larval arrival (recruitment) of this species at multiple sites spanning the reported latitudinal break. Together with surveys of adult abundance and satellite-based information of environmental (oceanographic) variables for the region $\left(28-34^{\circ} \mathrm{S}\right)$, and the development of neutral microsatellite markers, we assessed the potential influence of nearshore environmental, 
demographic, and geographic factors on the genetic diversity and population structure patterns of $N$. scabrosus. Using neutral markers of gene flow allowed us to (1) characterize patterns of genetic diversity and the spatial genetic structure in N. scabrosus and (2) determine the relative importance of environmental, demographic, and geographic factors for genetic variation between and within populations of this widely distributed barnacle species.

\section{MATERIALS AND METHODS}

\subsection{Hydrography of the study area}

The coast of Chile between 18 and $42^{\circ} \mathrm{S}$ is under the broad influence of the northward flowing Humboldt Current (also called Chile-Peru Current). Close to shore, coastal hydrography is dominated by the dynamics of the Chilean Coastal Current (CCC), a predominantly northward surface stream forced by the prevailing south and southwest upwelling-favorable winds (Aiken et al. 2008, 2011), which intensify during spring and early summer months, and around coastal topographic features (Strub et al. 1998, Tapia et al. 2009, Bravo et al. 2016). Our study area is located in a fairly straight shoreline stretch (Fig. 1) and is exposed to direct wave action (Narváez et al. 2006).

Within the study area, the main upwelling centers are Punta Talca, Punta Toro, Curaumilla, Pichilemu, and, to a lesser extent, Los Molles (Silva \& Valdenegro 2003, Wieters et al. 2003, Tapia et al. 2009, 2014). In contrast, the bays of Cartagena, Valparaíso, and Coquimbo remain relatively protected from upwelling (Kaplan et al. 2003, Vargas et al. 2004, Aiken et al. 2008). Four sampling sites (PTal, LMol, Cura, and Pich) were located in active upwelling centers, and 4 sites, namely Temb and Guan (Coquimbo Bay), Mont (Valparaíso Bay), and ECIM (Cartagena Bay), were located in places of weak upwelling. For the 2 remaining sites (Apol and CBaj), records from in situ SST suggest that the hydrography of Apol may be similar to that of weak upwelling sites, while CBaj seems to be under the influence of active upwelling (Valdivia et al. 2015).

An important geographic discontinuity in upwelling-favorable winds occurs around 30-32 S (Strub et al. 1998, Thomas 1999, Hormazabal et al. 2004, Navarrete et al. 2005). North of this latitude, equatorward winds are weaker but more persistent throughout the year, while to the south winds are stronger but temporarily more variable (Hormazabal et al. 2004, Navarrete et al. 2005). The change in oceanographic regimes determines or modulates the concentration and temporal variability of surface phytoplankton (Thomas 1999), nutrient regimes $\left(\mathrm{NO}_{3}\right)$ of coastal waters (Tapia et al. 2014), and functional structure of benthic communities (Broitman et al. 2001, Navarrete et al. 2005, Wieters et al. 2009).

\subsection{Study species}

Notochthamalus scabrosus is distributed along most of the rocky coasts of Ecuador, Peru, and Chile (Brattström \& Johanssen 1983). In the zone occupied by chthamalid barnacles, $N$. scabrosus inhabits the 3 intertidal elevations, with greater abundance in the middle and upper intertidal zones (Paine et al. 1985, Shinen \& Navarrete 2010). Adults are sessile filter feeding, hermaphroditic brooders. The life cycle of $N$. scabrosus includes a pelagic larval stage that lasts about $37 \mathrm{~d}$ at $15-18^{\circ} \mathrm{C}$, with 6 naupliar stages with planktotrophic feeding and a cyprid stage competent for settlement (Venegas et al. 2000). 
Cyprid settlement occurs in pulses of larval arrival to the coast during a few days within the recruitment period, which is mainly concentrated in spring-summer (Tapia \& Navarrete 2010).

\subsection{Sampling of individuals, DNA extraction, and genotyping of microsatellites}

At each of 10 study sites, $30 \mathrm{~N}$. scabrosus adults of 3-6.4 mm rostrocranial length were collected from rocky platforms approximately $10-30 \mathrm{~m}$ long $\times 4-8 \mathrm{~m}$ wide. Individual barnacles were identified as $N$. scabrosus in the field and were removed from the rock with a scalpel and immediately stored in tubes with $95 \%$ ethanol for preservation. Total DNA was extracted using the salt/Proteinase K method (Aljanabi \& Martinez 1997) and quantified in a spectrophotometer (Nanodrop).

Seven microsatellite loci were amplified by polymerase chain reaction (PCR). The microsatellite development procedure, the conditions under which the PCRs were performed, and the GenBank accession numbers can be found in Table S1 in the Supplement at www.int-res/articles/suppl/m123p456_supp.pdf. Alleles were identified by capillary electrophoresis in an ABI3130 Genetic Analyzer (Applied Biosystems), and the Excel FLEXIBIN macro (Amos et al. 2007) was used to calibrate the reading and allele binning of each locus.

\subsection{Genetic polymorphism}

The total number of observed alleles $(\mathrm{Na})$, number of private alleles $(\mathrm{Pa})$, and observed $\left(H_{\mathrm{o}}\right)$ and expected $\left(H_{\mathrm{e}}\right)$ heterozygosity were calculated in GENALEX 6.5 (Peakall $\&$ Smouse 2012). Per locus gene diversity (Gd) and standardized allelic richness (Ar) were calculated in the FSTAT software version 2.9.3.2 (Goudet 2001). The Ar index was calculated using the rarefaction method to avoid bias due to differences in sample size (Leberg 2002). To evaluate deviations from the Hardy-Weinberg expectations (HWE), Fisher's exact tests were performed for heterozygote deficits at each site-locus combination, and $U$-score tests for global HWE per site through loci and per locus across sites (dememorization 10000; 100 batches; 10000 iterations) using the GENEPOP 4.2 software (Rousset 2008). Linkage disequilibrium between all pairs of loci at each site and between each pair of loci across sites was assessed by Fisher's exact tests implemented in GENEPOP with this same parameter set. The inbreeding coefficient $F_{\text {IS }}$ by locus and site was quantified with GENETIX 4.05 (Belkhir et al. 2004), and departures from random expectations were assessed by 10000 permutations. For all multiple comparisons, the nominal level of significance of 5\% was adjusted using the false discovery rate (FDR; Benjamini \& Hochberg 1995).

To test for large allele dropout and stuttering and to estimate the frequency of null alleles at each site-locus combination following Brookfield (1996: Eq. 4), data were analyzed with the MICROCHECKER software (van Oosterhout et al. 2004).

\subsection{Population genetic structure}

Global and pairwise genetic differentiation was evaluated calculating $\theta_{\text {ST }}$ (Weir \& Cockerham 1984) and $D_{\mathrm{EST}}$ (Jost 2008) indices, in GENALEX 6.5 (Peakall \& Smouse 2012) and running 10000 permutations to evaluate their significance. Jost's $D_{\mathrm{EST}}$ outperforms $G_{\mathrm{ST}}$ and its relatives $\left(F_{\mathrm{ST}}\right)$ over a range of sample sizes, including in situations 
where we have highly variable microsatellite loci with different numbers of alleles (Heller \& Siegismund 2009, Gerlach et al. 2010), but it is recommended to compare results between differentiation indices (Leng \& Zhang 2011). In all multiple comparisons, sites were used as population units, and the nominal level of significance, $5 \%$, was adjusted using FDR. To identify population relationships in a 2-dimensional space, principal coordinate analyses (PCoAs) of the sites were computed and graphed in GENALEX 6.5 using the $\theta_{\mathrm{ST}}$ and $D_{\mathrm{EST}}$ differentiation indices.

As null alleles can impose error in differentiation estimates (Pompanon et al. 2005), 2 approximations were conducted. First, using MICROCHECKER, we obtained a new database corrected for null alleles. MICROCHECKER adjusts the number of homozygote genotypes to reflect the estimated frequency of null alleles and the likely number of homozygotes given the adjusted allele frequencies and assuming random mating. We then repeated the previous differentiation analysis using the database adjusted by the frequency of null alleles. Second, pairwise $F_{\mathrm{ST}}$ with and without the null allele correction was estimated using the expectation-maximization (EM) algorithm (Dempster et al. 1977) with ENA correction to give an accurate estimate of $F_{\mathrm{ST}}$ in the presence of null alleles using FREENA (Chapuis \& Estoup 2007). The uncorrected and corrected pairwise $F_{\text {ST }}$ were then compared by means of a paired $t$-test.

To estimate the number of genetically differentiated groups, Bayesian-based clustering was used as implemented in STRUCTURE 2.3.4 (Pritchard et al. 2000). STRUCTURE was run using the admixture model, the assumption of correlated allelic frequencies between clusters, with and without the recessive alleles option that accounts for the null alleles (Falush et al. 2003, 2007), and considering sampling site information (Hubisz et al. 2009). From Zakas et al. (2009) and Laughlin et al. (2012), we know that $k=$ 1 can be rejected, so all runs were made for $k$ values between 2 and 10. Ten independent runs with 500000 Markov chain Monte Carlo replicates and a burn-in length of 50000 were used for each value of $k$. In order to select the $k$ value that best captures the structure of the data, the statistic $\Delta k$, a measure of the second-order rate of change in the likelihood of $k$ (Evanno et al. 2005) was implemented in STRUCTURE HARVESTER (Earl \& vonHoldt 2012), and the values of $\Delta k$ as a function of $k$ were plotted. In CLUMPP 1.1 (Jakobsson \& Rosenberg 2007), we merged the results of the 10 runs for each value of $k$, and DISTRUCT 1.1 (Rosenberg 2004) was used to graphically visualize the results.

\subsection{Demographic variables}

\subsubsection{Recruitment rates}

At each site, an estimate of arrival rates of larval $N$. scabrosus was obtained by quantifying recruitment onto $10 \times 10 \mathrm{~cm}$ Plexiglas plates covered with SafetyWalk ${ }^{\mathrm{TM}}(3 \mathrm{M})$, an anti-slip surface that provides a heterogeneous substrate for larvae settlement and ensures homogeneity of conditions across plates and sites (Menge 2000). Five replicate collectors were fastened to the rocky substrate with stainless-steel bolts in the mid-upper intertidal zones of rocky platforms exposed to swell. Replicate collectors were replaced monthly, and recruitment rates were standardized to the number of ind. collector ${ }^{-1} \mathrm{~d}^{-1}$. The monthly recruitment rates were then averaged to obtain the annual recruitment rates, and these in turn were averaged over the years to estimate the per site recruitment rate. At 8 of the 10 study sites, the collectors were initially deployed in late 1999 or early 2000 , whereas 
at the 2 northernmost sites (CBaj and Apol), recruitment surveys began in mid-2009. The recruitment time series used here covered the period up to December 2013 for all sites.

\subsubsection{Adult cover (abundance)}

At each site, the benthic abundance of $N$. scabrosus was estimated using 7 to 10 quadrats of $0.25 \mathrm{~m}^{2}$, located along ca. 20-30 m alongshore transects. Transects were repeated at 3 intertidal elevations (low, mid-, and high intertidal zones) of the same rocky platforms where we deployed larval collectors. The $50 \times 50 \mathrm{~cm}$ quadrat frame was divided into 25 equal squares with monofilament line, which was used to visually estimate adult abundance of $N$. scabrosus as percentage cover. Cover surveys were conducted approximately every 6 mo. For more details about the field methods, see Broitman et al. (2011).

\subsection{Environmental and geographic variables}

Environmental heterogeneity imposed by hydrographic conditions such as SST and productivity can directly or indirectly affect population genetic structure in marine organisms (Bekkevold et al. 2005, Mendez et al. 2010, Wei et al. 2013). A multivariate indicator of environmental variability was constructed to test for correlation with the spatial genetic structure of $N$. scabrosus. To this end, spatio-temporal variations in chlorophyll $a$ (chl $a$ ) concentration $\left(\mathrm{mg} \mathrm{m}^{-3}\right)$ and SST $\left({ }^{\circ} \mathrm{C}\right)$ over a period of $10 \mathrm{yr}$ (January 2003 to December 2013) were processed from monthly averages of Aqua MODIS satellite data with a $4 \mathrm{~km}$ spatial resolution using MatLab R2014a. Temporal variability in chl $a$ and SST across the region was then decomposed by 2 separate principal component analyses (PCAs) of the respective time series, so that scores of sites on PC1 and PC2 (typically called empirical orthogonal function (EOF1 and EOF2) in the oceanographic literature, as they are carried out in the time domain), were used as multivariate representations of environmental conditions for either SST or chl $a$. In these analyses, the first axis (PC1) is dominated by the seasonal amplitude, with positive/negative values corresponding to sites with strong/weak seasonality. The second mode (PC2) is dominated by higher frequency variability, which in our system is chiefly synoptic variation corresponding to upwelling dynamics (see Wieters et al. 2009, Tapia et al. 2014, Valdivia et al. 2015 for similar analyses). Latitudinal (Lat) and longitudinal (Lon) positions of each site were used as descriptors of geographic structure.

\subsection{Environmental/demographic/geographic-genetic association analysis}

Three complementary approaches, i.e. simple linear regressions, multi model selection, and matrix regression, were employed to test for associations among environmental, demographic, and geographic factors with the spatially structured genetic diversity of $N$. scabrosus. The linear regressions and model selection analyses used location (site)-specific data to evaluate the influence of our explicative variables on genetic diversity across sampling sites. The matrix regression analyses used the explicative variables as a proxy of 'seascape resistance' (McRae 2006) to evaluate their effects on among-site genetic differentiation. Our 8 predictive variables were the PC1 and PC2 of chl $a$ and SST (hereafter CHLA1, CHLA2, SST1, and SST2), long-term averages of recruitment rates (Rec) and adult cover (Cov), and geographic location (Lat and Lon). The variables Rec and Cov were $\log _{10}$ transformed before analyses to approximate normal distributions. 
First, we conducted least squares (LS) linear multiple regression analyses between each metric of genetic diversity ( $\mathrm{Ar}$ and $\mathrm{Gd}$ ) and our 8 predictive variables. Second, a sensitivity analysis was performed using generalized linear models (GLMs) to select the best model of variables to explain spatial variation in our metrics of genetic diversity. Because some predictor variables are highly correlated (see Table S3), we examined the impact of collinearity using the variance inflation factor (VIF) before running analyses. The variables Lat, Rec, and SST2 showed high $(>10)$ VIF values, and were removed to minimize VIF values $(<5)$. We then followed a stepwise approach for the sensitivity analysis, which was repeated for the 2 dependent variables (Ar and Gd) in R (R Core Development Team 2017): We (1) ran a full GLM that includes all predictive variables with VIF values <5; (2) examined the scatterplot of residuals versus predicted values (both in terms of the slope of the relationship and in the dispersion of the values) to check for the absence of trends; (3) sequentially removed (one by one) all predictive variables that were not significant ( $p>0.05$ ); (4) selected the most parsimonious 'suboptimal' GLM through a manual stepwise procedure according to the relative contribution of each factor to the variance explained by the model retaining predictive variables with a relative contribution $\geq 10 \%$; (5) computed LS means of the dependent variable for each model parameter in order to assess the effect of specific variables on the dependent variables.

As an alternative way to obtain the best subset of explicative variables, we performed stepwise selection (both forward and backward) using the stepAIC function from the 'mass' package in R. This function uses the exact Akaike's information criterion (AIC) as the model selection criterion. Third, we used multiple regressions on distance matrices (MRDM; Manly 1986, Legendre et al. 1994) to estimate the independent effects of explicative variables on $N$. scabrosus among-site genetic differentiation. Briefly, partial regression slopes were estimated using standard multiple linear regression, but the significance of each term was determined by randomly permuting the explanatory variables one at a time while keeping the others constant (Wang 2013). This analysis was implemented using the 'ecodist' package (Goslee \& Urban 2007) in R, and significance was based on 10000 permutations using the genetic distance matrices $\left(\theta_{\mathrm{ST}}\right.$ and $\left.D_{\mathrm{EST}}\right)$ as response variables. Each of 8 matrices representing environmental, demographic, and geographic differences among sites were used as the predictor variables. Data were converted into matrices of pairwise distances calculating the absolute differences from sitespecific values of each variable following Amaral et al. (2012). Due to its high VIF value $(>10)$, the geographical variable Lat was removed, so a subset of 7 predictor variables was retained for the subsequent analysis.

\section{RESULTS}

\subsection{Genetic polymorphism}

The 7 microsatellite loci reached a total of 158 alleles in the 300 individuals of Notochthamalus scabrosus genotyped, which ranged from 79 in CBaj to 95 in Temb. In addition, we found 27 private alleles, with the highest number observed at Apol $(\mathrm{Pa}=6)$. In contrast, Pich shared all of its alleles with most other sites. The Ar ranged from 11.0 in CBaj to 13.2 in Temb (mean $\mathrm{Ar}=12.01 \pm 0.72$ ), while Gd ranged from 0.77 in ECIM to 0.83 in Apol (mean $\mathrm{Gd}=0.81 \pm 0.02$ ). Both Ar and Gd indices showed a peak at Guan, 
Temb and Apol (located around Coquimbo Bay), while the lowest values were found at CBaj and ECIM for Ar, and at ECIM and Mont for Gd (Table S2).

All 10 populations exhibited significant heterozygote deficiency. Of the 70 sitelocus combinations, 58 showed a significant deviation from HWE based on Fisher's exact test and after FDR correction, while only 37 had significantly positive $F_{\text {IS-values based on }}$ a permutation test (Table S2). Using the corrected database for null alleles, 56 site-locus combinations remained significantly deviating from HWE with the exact test, and 30 sitelocus comparisons still had significant $F_{\text {IS }}>0$ with permutation tests (Table $\mathrm{S} 2$ ).

Of the 210 linkage disequilibrium tests performed, none was significant after correcting for false positives (FDR), and none of the global tests for each pair of loci across sites was significant. The estimated frequency of null alleles by site-locus combination varied between 0 and 0.379 , with an average frequency of $0.156(\mathrm{SD}=0.089)$ across loci and sites (Table S2).

\subsection{Population genetic structure}

$N$. scabrosus showed statistically significant global genetic structure $\left(\theta_{\mathrm{ST}}=0.013, \mathrm{p}\right.$ $\left.<0.001 ; D_{\mathrm{EST}}=0.040, \mathrm{p}<0.001\right)$. Pairwise $\theta_{\mathrm{ST}}$ and $D_{\mathrm{EST}}$ were significant for 27 and 21 of the 45 comparisons at the nominal level $(\alpha=0.05)$, of which 22 and 15 remained significant after corrections for multiple tests, respectively (Table 1). Significant pairwise comparisons were mostly between sites north of PTal versus sites south of LMol, and the sites with lowest and highest levels of differentiation were Guan vs. PTal (separated by $50.26 \mathrm{~km}$ ) and Temb vs. Cura (separated by $419.88 \mathrm{~km}$ ), respectively. CBaj had the highest number of significant pairwise comparisons for both $\theta_{\mathrm{ST}}$ and $D_{\mathrm{EST}}(\mathrm{n}=9$ and 8 , respectively) followed by $\mathrm{LMol}$ ( $\mathrm{n}=7$ and 6 , respectively; Table 1 ). The first 2 coordinates of PCoAs with $\theta_{\mathrm{ST}}$ and $D_{\mathrm{EST}}$ values explained 87.62 and $87.88 \%$ of total variation, respectively, and revealed similar structuring of sites (Fig. 2). The first axis of the PCoAs separated 2 principal groups, one composed of sites from LMol to the south, the other with the 3 northern sites (Temb, Apol, and CBaj), whilst Guan and PTal were between these 2 groups. Weak separation of sites within these regions was detected along the second PCoA axis, with Temb separated from Apol and CBaj, and LMol and Cura from Mont, ECIM, and Pich (Fig. 2).

Null alleles had some effect on our results: (1) the ENA method gave slightly, but significantly, lower $F_{\mathrm{ST}}$ values (average $F_{\mathrm{ST}}$ with $\mathrm{ENA}=0.00815, \mathrm{SD}=0.00693$ ) than those obtained without correction for the presence of null alleles (average $F_{\text {ST }}$ without ENA $=0.00951, \mathrm{SD}=0.00847$; paired $t=3.74, \mathrm{p}<0.001) ;(2)$ global structure was lower but still significant with the adjusted database $\left(\theta_{\mathrm{ST}}=0.012, \mathrm{p}<0.001 ; D_{\mathrm{EST}}=0.018, \mathrm{p}=\right.$ 0.001 ); and (3) there were fewer significant pairwise comparisons after FDR corrections for $D_{\text {EST }}$ (only 1 significant comparison) and $\theta_{\mathrm{ST}}(15$ of 22 comparisons still significant). However, the main pattern of differentiation between sites north and south of PTal-LMol persisted with the adjusted database, as well as the most and least differentiated pairwise comparisons (Table 1).

The cluster analysis performed using STRUCTURE confirmed the existence of 2 clusters, one south of LMol and the other north of PTal (Fig. 3). For $k=3$, a new cluster included CBaj, the northernmost site. According to Evanno's criteria, $k=4$ was the most likely number of clusters (Fig. S1). However, no clear spatial pattern could be recovered 
from the assignment of individuals into these 4 clusters. This may be due to the correlated allele frequencies model, which tolerates differentiation of closely related populations, but is likely to overestimate $k$ (Pritchard et al. 2000). The same trends were observed with the full or the adjusted databases (results not shown).

\subsection{Demographic/geographic/environmental-genetic association analysis}

Linear regressions showed that CHLA2 alone explained 48 and $61 \%$ of the total variance in $\mathrm{Ar}$ and $\mathrm{Gd}$, respectively, having a significant positive linear relationship with both genetic diversity indices throughout the study region (Fig. 4). Additionally, Cov explained 33\% of the variance of Ar, and SST2 and Lat explained 25 and $30 \%$ of the variance of $\mathrm{Gd}$, respectively, but these relationships were not statistically significant (Fig. 4).

Statistical control of covariables using GLM model selection identified the variable CHLA2 as the most significant factor explaining variation in both Ar and Gd (Table 2). The second and third best models include the variables CHLA1 and Cov, which is consistent with results of the model selection based on AIC (Table 3), but the fraction of variance explained by these variables was minor in comparison to CHLA2 (see Table 2).

A different result was obtained from the MRDM analysis, which showed that the spatial structure (differences among sites) in SST2 and Cov had the strongest effects on genetic differentiation, as measured by $\theta_{\text {ST }}$ and $D_{\text {EST. The overall model showed significant }}$ fit to the data $(\mathrm{p}<0.05)$, and explained $55 \%$ of the total variance (Table 4$)$.

\section{DISCUSSION}

The extent of effective dispersal and gene flow between populations in the coastal ocean can be much more complex than previously thought (e.g. Pringle \& Wares 2007, Teske et al. 2016). In the present study, we found subtle, yet significant levels of genetic differentiation in the intertidal barnacle Notochthamalus scabrosus, a species with high dispersal potential. Main differences occurred between sites located to the north and south of the reported phylogeographic latitudinal break at $30^{\circ} \mathrm{S}$.

Our results suggest that population genetic diversity in N. scabrosus is influenced by environmental regimes manifested in patterns of temporal variability of surface chl $a$ concentration, whereas among-site differences in SST fluctuations and benthic abundance of adults appear to be significant drivers of population genetic differentiation over space. More broadly, the presence of sites that are both environmentally and genetically differentiated supports the idea of an ecological restriction to population connectivity, despite the long residence of larvae in the water column.

Larval arrival from the plankton can be responsible for local abundance and genetic variability patterns of benthic populations (Iacchei et al. 2013). We found that the temporal variability in surface chl $a$ was the most consistent covariable explaining spatial distribution of $N$. scabrosus genetic diversity. This general result is in line with studies showing that patterns of intraspecific genetic diversity of some mobile marine species are associated with variation in chlorophyll concentration (Gaggiotti et al. 2009, Mendez et al. 2010, Amaral et al. 2012). Variability in coastal chl $a$ may be viewed as an integrated indicator of the environmental conditions to which invertebrate larvae and onshore adults are exposed, and 
likely determines both the feeding conditions (i.e. quantity and quality of food) and the larval transport to/off the shore. During upwelling, high food availability can translate into better larval condition and, at the same time, offshore and alongshore upwelling currents can promote the mixing of the offshore larval pool (Barshis et al. 2011). Then, during upwelling relaxation and downwelling events, this well fed/well mixed larval pool can reach local populations. In this manner, sites with constant strong upwelling have few possibilities of larval arrival due to increased larval waste (Roughgarden et al. 1988, Menge \& Menge 2013), while on the other hand, sites with constant weak upwelling have more larval retention, therefore their recruitment comes from a poorly mixed larval pool. Other things being equal or homogeneous, high phytoplankton availability in coastal waters during larval development can therefore lead to higher recruitment (e.g. Olson \& Olson 1989, Cushing 1990, Menge 2000) and high larval physiological quality that should improve post-settlement survival (Jarrett \& Pechenik 1997, Hentschel \& Emlet 2000, Phillips 2002) as well as overall juvenile condition (Bertness et al. 1991, Menge et al. 1997, Sanford \& Menge 2001). All of these factors may result in the maintenance of genetic diversity from the larval pool. Thus, variable upwelling will maximize larval condition and genetic diversity and, as predicted by the intermittent upwelling hypothesis (Menge \& Menge 2013), increase onshore recruitment. Further genetic studies should therefore intensify sampling of recently settled larvae across more diverse upwelling conditions. Indirect evidence about the effect of upwelling/relaxation dynamics on barnacle recruitment (Navarrete et al. 2005, Lagos et al. 2008) and the significant positive cross-correlations between mean chl $a$ concentration and $N$. scabrosus recruitment and adult abundance (Table S3) suggest that it is a possible mechanism to explain the genetic pattern in $N$. scabrosus.

Adult cover was used as a proxy of local abundance of $N$. scabrosus, a factor that in linear regressions explained 33\% of total variance in allelic richness (although it was not statistically significant, Fig. 4). From examination of Fig. 4f, it seems clear that the site ECIM deviates largely from an otherwise good positive relationship formed by the other 9 sites. Indeed, removing ECIM from the analysis increases the relationship to $\mathrm{r}^{2}=0.57$ ( $\mathrm{p}=$ 0.019). The departure of ECIM from the general pattern illustrates well the complexity of determinants of genetic diversity in natural systems and why such univariate relationships between population size and genetic diversity are rarely found in marine environments (but see McCusker \& Bentzen 2010). ECIM has some of the historically highest recruitment rates for N. scabrosus in the region (Navarrete et al. 2008), yet it displays one of the lowest levels of genetic diversity (in both Ar and Gd indices, Table S2). Furthermore, only at ECIM did individuals have levels of relatedness significantly larger than expected from HWE (Fig. S2).

ECIM is located within Cartagena Bay, an open bay exposed to the southern swell, but in an 'upwelling shadow' where upwelling advection is largely reduced, apparently leading to high phytoplankton concentration (Wieters et al. 2003) and stronger stratification than other sites (Kaplan et al. 2003, Bonicelli et al. 2014). On other shores of the world, low current velocities and water re-circulation, leading to increased local larval retention (McShane et al. 1988), create distinctive patterns of genetic diversity in local populations (e.g. Dupont et al. 2007, Nicastro et al. 2008, Olivares-Bañuelos et al. 2008). Thus, increased larval retention at ECIM, with comparatively low immigration from other populations, as suggested by numerical circulation models (Aiken et al. 2007, Ospina- 
Alvarez et al. 2018) and observational studies (Bonicelli et al. 2014), may explain the higher genetic relatedness levels observed at this site. The reduced gains of genetic diversity from other sites (poorly mixed larval pool) may be the cause of reduced allelic richness, further supporting the relevance of connectivity patterns on adult population size and genetic diversity.

In natural populations, a genetic discontinuity along a continuously colonized range can arise as a consequence of an environmental discontinuity, either through selection against migrants or reduced fitness of interlineage hybrids (Nosil et al. 2005). Both mechanisms involve local adaptation in response to selection imposed by divergent biotic or abiotic conditions (Sanford \& Kelly 2011, Pflüger \& Balkenhol 2014). Our results support the idea that 'environmental distance,' imposed by among-site differences in SST, is a relevant factor to explain genetic differentiation among $N$. scabrosus populations. Indeed, a similar effect has been observed in mammals (Fullard et al. 2000, Amaral et al. 2012), fishes (Han et al. 2012, Diopere et al. 2018), and intertidal and shallow ( $<5 \mathrm{~m}$ depth) coastal invertebrate species (Banks et al. 2010, Wei et al. 2013). Seawater temperature is also one of the most important factors controlling reproduction, development, and growth of ectothermic invertebrates (Pechenik 1987, O'Connor et al. 2007, Byrne 2011). In the case of $N$. scabrosus, such adaptive divergence could be related to selective sorting of competent larvae and/or to post-settlement processes such as temperature requirements for metamorphosis and initial growth, or desiccation tolerance of recruits. Further studies combining genomic tools with high-resolution dispersal models and local experiments with settlers are necessary to discern among the possible mechanisms of population divergence.

\section{CONCLUSION}

Population genetic structure of Notochthamalus scabrosus, as assessed by neutral markers, is characterized by a sharp genetic discontinuity around $30^{\circ} \mathrm{S}$, confirming previous conclusions based on mtCOI (Zakas et al. 2009, Laughlin et al. 2012). A modeling study by Ewers-Saucedo et al. (2016) showed that dispersal alone could not generate such genetic discontinuity, and that differential lineage performance in adjacent but divergent environments must be considered. Our results strongly suggest that the environment is indeed influencing the spatial pattern of genetic diversity in N. scabrosus. Two main mechanisms could be hypothesized: temporal variability of the food (variation in phytoplankton abundance) and dispersive (upwelling-associated currents) coastal environments favor recruitment from a well fed/well mixed larval pool and therefore increase the allelic richness of benthic populations; and the ecological divergence in coastal ocean temperature may restrict effective dispersal across the $30^{\circ} \mathrm{S}$ boundary. Such patterns have not been observed in other barnacles, which are traditionally assumed to have large effective population sizes and large dispersal capacity, both of which could override the effects mentioned above. We interpret these results as suggestive that coastal circulation can limit larval connectivity among some populations, generating incomplete barriers to dispersal, which in turns facilitates effects of isolation by environment. Hence, the results of this work advance our understanding of how environmental seascapes can shape patterns of genetic diversity and population differentiation. In particular, our results highlight the importance of further defining the causal relationships between environmental variables and genetic diversity patterns of wild populations in order to guide future region-wide conservation and management efforts. 
Acknowledgements. We thank to members of B.R.B.'s and S.A.N.'s groups for field assistance, as well as Gioconda Peralta for her guidance during DNA sequencing analyses. M.B. was supported by a CONICYT Doctoral Fellowship. The research was supported by the Center for Marine Conservation (grant ICM CCM RC130004) and the Center for Multiple Drivers of Marine Socio-Ecological Systems (grant ICM MUSELS NC120086), both of the Iniciativa Científica Milenio of the Ministerio de Economia, Fomento y Turismo. Further support for field work and oceanographic studies was provided by FONDECYT (grants 1160289 to S.A.N. and 1181300 to B.R.B.).

\section{LITERATURE CITED}

Aguirre C, Garreaud RD, Rutllant JA (2014) Surface ocean response to synoptic-scale variability in wind stress and heat fluxes off south-central Chile. Dyn Atmos Oceans 65:64-85 doi:10.1016/j.dynatmoce.2013.11.001

Aiken CM, Navarrete SA, Castillo MI, Castilla JC (2007) Along-shore larval dispersal kernels in a numerical ocean model of the central Chilean coast. Mar Ecol Prog Ser 339:13-24 doi:10.3354/meps339013

Aiken CM, Castillo MI, Navarrete SA (2008) A simulation of the Chilean Coastal Current and associated topographic upwelling near Valparaíso, Chile. Cont Shelf Res 28:23712381 doi:10.1016/j.csr.2008.05.006

Aiken CM, Navarrete SA, Pelegrí JL (2011) Potential changes in larval dispersal and alongshore connectivity on the central Chilean coast due to an altered wind climate. $\mathrm{J}$ Geophys Res 116:G04026 doi:10.1029/2011JG001731

Aljanabi SM, Martinez I (1997) Universal and rapid salt-extraction of high quality genomic DNA for PCR-based techniques. Nucleic Acids Res 25:4692-4693 PubMed doi:10.1093/nar/25.22.4692

Amaral AR, Beheregaray LB, Bilgmann K, Boutov D and others (2012) Seascape genetics of a globally distributed, highly mobile marine mammal: the short-beaked common dolphin (genus Delphinus). PLOS ONE 7:e31482 PubMed doi:10.1371/journal.pone.0031482

Amos W, Hoffman JI, Frodsham A, Zhang L, Best S, Hill VS (2007) Automated binning of microsatellite alleles: problems and solutions. Mol Ecol Notes 7:10-14 doi:10.1111/j.1471-8286.2006.01560.x

Banks SC, Ling SD, Johnson CR, Piggott MP, Williamson JE, Beheregaray LB (2010) Genetic structure of a recent climate change-driven range extension. Mol Ecol 19:20112024 PubMed doi:10.1111/j.1365-294X.2010.04627.x

Barshis DJ, Sotka EE, Kelly RP, Sivasundar A, Menge BA, Barth JA, Palumbi SR (2011) Coastal upwelling is linked to temporal genetic variability in the acorn barnacle Balanus glandula. Mar Ecol Prog Ser 439:139-150 doi:10.3354/meps09339 
Bekkevold D, André C, Dahlgren TG, Clausen LAW and others (2005) Environmental correlates of population differentiation in Atlantic herring. Evolution 59:2656-2668 PubMed doi:10.1111/j.0014-3820.2005.tb00977.x

Belkhir K, Borsa P, Chikhi L, Raufaste N, Bonhomme F (2004) GENETIX 4.04, logiciel sous Windows TM pour la génétique des populations. Laboratorie Génome, populations, interactions, CNRS UMR 5171, Université de Montpellier II, Montpellier

Benjamini Y, Hochberg Y (1995) Controlling the false discovery rate: a practical and powerful approach to multiple testing. J R Stat Soc B Methodol 57:289-300

Bertness MD, Gaines SD, Bermudez D, Sanford E (1991) Extreme spatial variation in the growth and reproductive output of the acorn barnacle Semibalanus balanoides. Mar Ecol Prog Ser 75:91-100 doi:10.3354/meps075091

Bonicelli J, Tapia FJ, Navarrete SA (2014) Wind-driven diurnal temperature variability across a small bay and the spatial pattern of intertidal barnacle settlement. J Exp Mar Biol Ecol 461:350-356 doi:10.1016/j.jembe.2014.09.003

Brattström H, Johanssen A (1983) Ecological and regional zoogeography of the marine benthic fauna of Chile. Sarsia 68:289-339 doi:10.1080/00364827.1983.10420583

Bravo L, Ramos M, Astudillo O, DeWitte B, Goubanova K (2016) Seasonal variability of the Ekman transport and pumping in the upwelling system off central-northern Chile $\left(\sim 30^{\circ} \mathrm{S}\right)$ based on a high-resolution atmospheric regional model (WRF). Ocean Sci 12:1049-1065 doi:10.5194/os-12-1049-2016

Broitman BR, Navarrete SA, Smith F, Gaines SD (2001) Geographic variation of southeastern Pacific intertidal communities. Mar Ecol Prog Ser 224:21-34 doi:10.3354/meps224021

Broitman BR, Véliz F, Manzur T, Wieters EA and others (2011) Geographic variation in diversity of wave exposed rocky intertidal communities along central Chile. Rev Chil Hist Nat 84:143-154 doi:10.4067/S0716-078X2011000100011

Brookfield JF (1996) A simple new method for estimating null allele frequency from heterozygote deficiency. Mol Ecol 5:453-455 PubMed doi:10.1111/j.1365294X.1996.tb00336.x

Byrne M (2011) Impact of ocean warming and ocean acidification on marine invertebrate life history stages: vulnerabilities and potential for persistence in a changing ocean. Oceanogr Mar Biol Annu Rev 49:1-42

Camus PA (2001) Biogeografía marina de Chile continental. Rev Chil Hist Nat 74:587617 doi:10.4067/S0716-078X2001000300008

Chapuis MP, Estoup A (2007) Microsatellite null alleles and estimation of population differentiation. Mol Biol Evol 24:621-631 PubMed doi:10.1093/molbev/msl191

Crutsinger GM, Collins MD, Fordyce JA, Gompert Z, Nice CC, Sanders NJ (2006) Plant genotypic diversity predicts community structure and governs an ecosystem process. Science 313:966-968 PubMed doi:10.1126/science.1128326 
Cushing DH (1990) Plankton production and year-class strength in fish populations:an update of the match /mismatch hypothesis. Adv Mar Biol 26:249-293 doi:10.1016/S0065-2881(08)60202-3

Darwin C (1854) A monograph on the subclass Cirripedia with figures of all the species. The Balanidae, the Berrucidae, etc. Ray Society, London

Dempster AP, Laird NM, Rubin DB (1977) Maximum likelihood from incomplete data via the EM algorithm. J R Stat Soc B Methodol 39:1-38

Dupont L, Ellien C, Viard F (2007) Limits to gene flow in the slipper limpet Crepidula fornicata as revealed by microsatellite data and a larval dispersal model. Mar Ecol Prog Ser 349:125-138 doi:10.3354/meps07098

Earl DA, vonHoldt BM (2012) STRUCTURE HARVESTER: a website and program for visualizing STRUCTURE output and implementing the Evanno method. Conserv Genet Resour 4:359-361 doi:10.1007/s12686-011-9548-7

Ellegren H, Galtier N (2016) Determinants of genetic diversity. Nat Rev Genet 17:422433 PubMed doi:10.1038/nrg.2016.58

Evanno G, Regnaut S, Goudet J (2005) Detecting the number of clusters of individuals using the software STRUCTURE: a simulation study. Mol Ecol 14:2611-2620 PubMed doi:10.1111/j.1365-294X.2005.02553.x

Ewers-Saucedo C, Pringle JM, Sepúlveda HH, Byers JE, Navarrete SA, Wares JP (2016) The oceanic concordance of phylogeography and biogeography: a case study in Notochthamalus. Ecol Evol 6:4403-4420 PubMed doi:10.1002/ece3.2205

Falush D, Stephens M, Pritchard JK (2003) Inference of population structure using multilocus genotype data: linked loci and correlated allele frequencies. Genetics 164:1567-1587 PubMed

Falush D, Stephens M, Pritchard JK (2007) Inference of population structure using multilocus genotype data: dominant markers and null alleles. Mol Ecol Notes 7:574578 PubMed doi:10.1111/j.1471-8286.2007.01758.x

Fullard KJ, Early G, Heide-Jørgensen MP, Bolch D, Rosing-Asvid A, Amos W (2000) Population structure of long-finned pilot whales in the North Atlantic: a correlation with sea surface temperature? Mol Ecol 9:949-958 PubMed doi:10.1046/j.1365294x.2000.00957.x

Gaggiotti OE, Bekkevold D, Jørgensen HB, Foll M, Carvalho GR, Andre C, Ruzzante DE (2009) Disentangling the effects of evolutionary, demographic, and environmental factors influencing genetic structure of natural populations: Atlantic herring as a case study. Evolution 63:2939-2951 PubMed doi:10.1111/j.1558-5646.2009.00779.x

Garavelli L, Kaplan DM, Colas F, Stortz W, Yannicelli B, Lett C (2014) Identifying appropriate spatial scales for marine conservation and management using a larval dispersal model: the case of Concholepas concholepas (loco) in Chile. Prog Oceanogr 124:42-53 doi:10.1016/j.pocean.2014.03.011 
635

636

637

638

639

640

641

642

643

644

645

646

647

648

649

650

651

652

653

654

655

656

657

658

659

660

661

662

663

664

665

666

667

668

669

670

671

672

673

674

675
Gerlach G, Jueterbock A, Kraemer P, Deppermann J, Harmand P (2010) Calculations of population differentiation based on GST and D: Forget GST but not all of statistics! Mol Ecol 19:3845-3852 PubMed doi:10.1111/j.1365-294X.2010.04784.x

Goslee S, Urban D (2007) The ecodist package for dissimilarity-based analysis of ecological data. J Stat Softw 22:1-19 doi:10.18637/jss.v022.i07

Goudet J (2001) FSTAT, version 2.9.3.2, A program to estimate and test gene diversities and fixation indices. Lausanne University

Han Z, Yanagimoto T, Zhang Y, Gao T (2012) Phylogeography study of Ammodytes personatus in Northwestern Pacific: Pleistocene isolation, temperature and current conducted secondary contact. PLOS ONE 7:e37425 PubMed doi:10.1371/journal.pone.0037425

Haye PA, Segovia NI, Muñoz-Herrera NC, Gálvez FE and others (2014) Phylogeographic structure in benthic marine invertebrates of the Southeast Pacific coast of Chile with differing dispersal potential. PLOS ONE 9:e88613 PubMed doi:10.1371/journal.pone.0088613

Hellberg ME (2009) Gene flow and isolation among populations of marine animals. Annu Rev Ecol Evol Syst 40:291-310 doi:10.1146/annurev.ecolsys.110308.120223

Heller R, Siegismund HR (2009) Relationship between three measures of genetic differentiation GST, DEST and G $\square$ ST: How wrong have we been? Mol Ecol 18:20802083 PubMed doi:10.1111/j.1365-294X.2009.04185.x

Hentschel BT, Emlet RB (2000) Metamorphosis of barnacle nauplii: effects of food variability and a comparison with amphibian models. Ecology 81:3495-3508 doi:10.1890/0012-9658(2000)081[3495:MOBNEO]2.0.CO;2

Hormazabal S, Shaffer G, Leth O (2004) Coastal transition zone off Chile. J Geophys Res 109:C01021 doi:10.1029/2003JC001956

Hubisz MJ, Falush D, Stephens M, Pritchard JK (2009) Inferring weak population structure with the assistance of sample group information. Mol Ecol Resour 9:13221332 PubMed doi:10.1111/j.1755-0998.2009.02591.x

Hughes AR, Inouye BD, Johnson MTJ, Underwood N, Vellend M (2008) Ecological consequences of genetic diversity. Ecol Lett 11:609-623 PubMed doi:10.1111/j.14610248.2008.01179.x

Iacchei M, Ben-Horin T, Selkoe KA, Bird CE, García-Rodríguez FJ, Toonen RJ (2013) Combined analyses of kinship and FST suggest potential divers of chaotic genetic patchiness in high gene-flow populations. Mol Ecol 22:3476-3494 PubMed doi:10.1111/mec. 12341

Jakobsson M, Rosenberg NA (2007) CLUMPP: a cluster matching and permutation program for dealing with label switching and multimodality in analysis of population structure. Bioinformatics 23:1801-1806 PubMed doi:10.1093/bioinformatics/btm233

Jarrett JN, Pechenik JA (1997) Temporal variation in cyprid quality and juvenile growth capacity for an intertidal barnacle. Ecology 78:1262-1265 doi:10.1890/00129658(1997)078[1262:TVICQA]2.0.CO;2 
676

Jost L (2008) GST and its relatives do not measure differentiation. Mol Ecol 17:40154026 PubMed doi:10.1111/j.1365-294X.2008.03887.x

Kaplan DM, Largier JL, Navarrete S, Guiñez R, Castilla JC (2003) Large diurnal temperature fluctuations in the nearshore water column. Estuar Coast Shelf Sci 57:385398 doi:10.1016/S0272-7714(02)00363-3

Lagos NA, Castilla JC, Broitman BR (2008) Spatial environmental correlates of intertidal recruitment: a test using barnacles in northern Chile. Ecol Monogr 78:245-261 doi:10.1890/07-0041.1

Lancellotti DA, Vasquez JA (1999) Biogeographical patterns of benthic macroinvertebrates in the Southern Pacific littoral. J Biogeogr 26:1001-1006 doi:10.1046/j.1365-2699.1999.00344.x

Largier JL (2003) Considerations in estimating larval dispersal distances from oceanographic data. Ecol Appl 13:71-89 doi:10.1890/10510761(2003)013[0071:CIELDD]2.0.CO;2

Laughlin KM, Ewers C, Wares JP (2012) Mitochondrial lineages in Notochthamalus scabrosus as indicators of coastal recruitment and interactions. Ecol Evol 2:1584-1591 PubMed doi:10.1002/ece3.283

Leberg PL (2002) Estimating allelic richness: effects of sample size and bottlenecks. Mol Ecol 11:2445-2449 PubMed doi:10.1046/j.1365-294X.2002.01612.x

Legendre P, Lapointe FJ, Casgrain P (1994) Modeling brain evolution from behavior: a permutational regression approach. Evolution 48:1487-1499 PubMed doi:10.1111/j.1558-5646.1994.tb02191.x

Leng L, Zhang DX (2011) Measuring population differentiation using GST or D? A simulation study with microsatellite DNA markers under a finite island model and nonequilibrium conditions. Mol Ecol 20:2494-2509 PubMed doi:10.1111/j.1365294X.2011.05108.x

Manly BJF (1986) Randomization and regression methods for testing for associations with geographical, environmental and biological distances between populations. Popul Ecol 28:201-218 doi:10.1007/BF02515450

McCusker MR, Bentzen P (2010) Positive relationships between genetic diversity and abundances in fishes. Mol Ecol 19:4852-4862 PubMed doi:10.1111/j.1365294X.2010.04822.x

McRae BH (2006) Isolation by resistance. Evolution 60:1551-1561 PubMed doi:10.1111/j.0014-3820.2006.tb00500.x

McShane PE, Black KP, Smith MG (1988) Recruitment processes in Haliotis rubra (Mollusca: Gastropoda) and regional hydrodynamics in southeastern Australia imply localized dispersal of larvae. J Exp Mar Biol Ecol 124:175-203 doi:10.1016/00220981(88)90171-2

Mendez M, Rosenbaum HC, Subramaniam A, Yackulic C, Bordinos P (2010) Isolation by environmental distance in mobile marine species: molecular ecology of franciscana 
dolphins at their southern range. Mol Ecol 19:2212-2228 PubMed doi:10.1111/j.1365294X.2010.04647.x

Menge BA (2000) Recruitment vs. postrecruitment processes as determinants of barnacle population abundance. Ecol Monogr 70:265-288 doi:10.1890/00129615(2000)070[0265:RVPPAD]2.0.CO;2

Menge BA, Menge DNL (2013) Dynamics of coastal meta-ecosystems: the intermittent upwelling hypothesis and a test in rocky intertidal regions. Ecol Monogr 83:283-310 doi:10.1890/12-1706.1

Menge BA, Daley BA, Wheeler PA, Straub PT (1997) Rocky intertidal oceanography: an association between community structure and nearshore phytoplankton concentration. Limnol Oceanogr 42:57-66 doi:10.4319/lo.1997.42.1.0057

Narváez DA, Navarrete SA, Largier J, Vargas CA (2006) Onshore advection of warm water, larval invertebrate settlement, and relaxation of upwelling off central Chile. Mar Ecol Prog Ser 309:159-173 doi:10.3354/meps309159

Navarrete SA, Wieters EA, Broitman BR, Castilla JC (2005) Scales of benthic-pelagic coupling and the intensity of species interactions: from recruitment limitation to topdown control. Proc Natl Acad Sci USA 102:18046-18051 PubMed doi:10.1073/pnas.0509119102

Navarrete SA, Broitman BR, Menge BA (2008) Interhemispheric comparison of recruitment to intertidal communities: pattern persistence and scales of variation. Ecology 89:1308-1322 PubMed doi:10.1890/07-0728.1

Nicastro KR, Zardi GI, McQuaid CD, Teske PR, Barker NP (2008) Coastal topography drives genetic structure in marine mussels. Mar Ecol Prog Ser 368:189-195 doi:10.3354/meps07607

Nickols KJ, White JW, Largier JL, Gaylord B (2015) Marine population connectivity: reconciling large-scale dispersal and high self-retention. Am Nat 185:196-211 PubMed doi:10.1086/679503

Nosil P, Vines TH, Funk DJ (2005) Reproductive isolation caused by natural selection against immigrants from divergent habitats. Evolution 59:705-719 PubMed

O’Connor MI, Bruno JF, Gaines SD, Halpern BS, Lester SE, Kinlan BP, Weiss JM (2007) Temperature control of larval dispersal and the implications for marine ecology, evolution, and conservation. Proc Natl Acad Sci USA 104:1266-1271 PubMed doi:10.1073/pnas.0603422104

Olivares-Bañuelos NC, Enríquez-Paredes LM, Ladah LM, De La Rosa-Véliz J (2008) Population structure of purple sea urchin Strongylocentrotus purpuratus along the Baja California peninsula. Fish Sci 74:804-812 doi:10.1111/j.1444-2906.2008.01592.x

Olson RR, Olson MH (1989) Food limitation of planktotrophic marine invertebrate larvae: Does it control recruitment success? Annu Rev Ecol Syst 20:225-247 doi:10.1146/annurev.es.20.110189.001301 
Ospina-Alvarez A, Weidberg N, Aiken CM, Navarrete SA (2018) Larval transport in the upwelling ecosystem of central Chile: the effects of vertical migration, developmental time and coastal topography on recruitment. Prog Oceanogr 168:82-99

Paine RT, Castilla JC, Cancino J (1985) Perturbation and recovery patterns of starfish dominated intertidal assemblages in Chile, New Zealand and Washington State. Am Nat 125:679-691 doi:10.1086/284371

Peakall R, Smouse PE (2012) GenAlEx 6.5: genetic analysis in Excel. Population genetic software for teaching and research - an update. Bioinformatics 28:2537-2539 PubMed doi:10.1093/bioinformatics/bts460

Pechenik JA (1987) Environmental influences on larval survival and development. In: Giese AC, Pearse JS, Pearse VB (eds) Reproduction of marine invertebrates, Vol 9. Blackwell Scientific Publications, Palo Alto, CA, p 551-608

Pflüger FJ, Balkenhol N (2014) A plea for simultaneously considering matrix quality and local environmental conditions when analyzing landscape impacts on effective dispersal. Mol Ecol 23:2146-2156 PubMed doi:10.1111/mec.12712

Phillips NE (2002) Effects of nutrition-mediated larval condition on juvenile performance in a marine mussel. Ecology 83:2562-2574 doi:10.1890/00129658(2002)083[2562:EONMLC]2.0.CO;2

Pompanon F, Bonin A, Bellemain E, Taberlet P (2005) Genotyping errors: causes, consequences and solutions. Nat Rev Genet 6:847-859 PubMed doi:10.1038/nrg1707

Pringle JM, Wares JP (2007) Going against the flow: maintenance of alongshore variation in allele frequencies in a coastal ocean. Mar Ecol Prog Ser 335:69-84 doi:10.3354/meps335069

Pringle JM, Blakeslee AMH, Byers JE, Roman J (2011) Asymmetric dispersal allows an upstream region to control population structure throughout a species' range. Proc Natl Acad Sci USA 108:15288-15293 PubMed doi:10.1073/pnas.1100473108

Pritchard JK, Stephens M, Donnelly P (2000) Inference of population structure using multilocus genotype data. Genetics 155:945-959

R Core Development Team (2017) R: a language and environment for statistical computing. R Foundation for Statistical Computing, Vienna

Reed DH, Frankham R (2003) Correlation between fitness and genetic diversity. Conserv Biol 17:230-237 doi:10.1046/j.1523-1739.2003.01236.x

Rosenberg NA (2004) DISTRUCT: a program for the graphical display of population structure. Mol Ecol Notes 4:137-138 doi:10.1046/j.1471-8286.2003.00566.x

Roughgarden J, Gaines S, Possingham H (1988) Recruitment dynamics in complex life cycles. Science 241:1460-1466 PubMed doi:10.1126/science.11538249

Rousset F (2008) GENEPOP'007: a complete re-implementation of the GENEPOP software for Windows and Linux. Mol Ecol Resour 8:103-106 PubMed doi:10.1111/j.1471-8286.2007.01931.x 
Sanford E, Kelly MW (2011) Local adaptation in marine invertebrates. Annu Rev Mar Sci 3:509-535 PubMed doi:10.1146/annurev-marine-120709-142756

Sanford E, Menge BA (2001) Spatial and temporal variation in barnacle growth in a coastal upwelling system. Mar Ecol Prog Ser 209:143-157 doi:10.3354/meps209143

Selkoe KA, D'Aloia CC, Crandall ED, Iacchei M and others (2016) A decade of seascape genetics: contributions to basic and applied marine connectivity. Mar Ecol Prog Ser 554:1-19 doi:10.3354/meps11792

Shinen JL, Navarrete SA (2010) Coexistence and intertidal zonation of chthamalid barnacles along central Chile: interference competition or a lottery for space? J Exp Mar Biol Ecol 392:176-187 doi:10.1016/j.jembe.2010.04.033

Silva N, Valdenegro A (2003) Evolución de un evento de surgencia frente a punta Curaumilla, Valparaíso. Investig Mar Valpso 31:73-89

Strub PT, Mesias J, Montecino V, Rutllant J, Salinas S (1998) Coastal ocean circulation off western South America. In: Robinson AR, Brink KH (eds) The sea, Vol 11. John Wiley, New York, NY, p 273-313

Tapia FJ, Navarrete SA (2010) Spatial patterns of barnacle settlement in central Chile: persistence at daily to inter-annual scales relative to the spatial signature of physical variability. J Exp Mar Biol Ecol 392:151-159 doi:10.1016/j.jembe.2010.04.031

Tapia FJ, Navarrete SA, Castillo M, Menge BA and others (2009) Thermal indices of upwelling effects on inner-shelf habitats. Prog Oceanogr 83:278-287 doi:10.1016/j.pocean.2009.07.035

Tapia FJ, Largier JL, Castillo M, Wieters EA, Navarrete SA (2014) Latitudinal discontinuity in thermal conditions along the nearshore of central-northern Chile. PLOS ONE 9:e110841 PubMed doi:10.1371/journal.pone.0110841

Tellier F, Meynard AP, Correa JA, Faugeron S, Valero M (2009) Phylogeographic analyses of the $30^{\circ} \mathrm{S}$ south-east Pacific biogeographic transition zone establish the occurrence of a sharp genetic discontinuity in the kelp Lessonia nigrescens: vicariance or parapatry? Mol Phylogenet Evol 53:679-693 PubMed doi:10.1016/j.ympev.2009.07.030

Teske PR, Sandoval-Castillo J, van Sebille E, Waters J, Beheregaray LB (2016) Oceanography promotes self-recruitment in a planktonic larval disperser. Sci Rep 6:34205 PubMed doi:10.1038/srep34205

Thomas AC (1999) Seasonal distribution of satellite-measured phytoplankton pigment concentration along the Chilean coast. J Geophys Res 104:25877-25890 doi:10.1029/1999JC900171

Valdivia N, Aguilera MA, Navarrete SA, Broitman BR (2015) Disentangling the effects of propagule supply and environmental filtering on the spatial structure of a rocky shore metacommunity. Mar Ecol Prog Ser 538:67-79 doi:10.3354/meps11493

van Oosterhout C, Hutchinson WF, Wills DPM, Shipley P (2004) MICRO-CHECKER: software for identifying and correcting genotyping errors in microsatellite data. Mol Ecol Notes 4:535-538 doi:10.1111/j.1471-8286.2004.00684.x 
835

836

837

838

839

840

841

842

843

844

845

846

847

848

849

850

851

852

853

854

855

856

857

858

859

860

861
Vargas CA, Narváez DA, Piñones A, Venegas RM, Navarrete SA (2004) Internal tidal bore warm fronts and settlement of invertebrates in central Chile. Estuar Coast Shelf Sci 61:603-612 doi:10.1016/j.ecss.2004.07.006

Venegas RM, Ortíz V, Olguín A, Navarrete SA (2000) Larval development of the intertidal barnacles Jehlius cirratus and Notochthamalus scabrosus (Cirripedia: Chthamalidae) under laboratory conditions. J Crustac Biol 20:495-504 doi:10.1163/20021975-99990065

Wang IJ (2013) Examining the full effects of landscape heterogeneity on spatial genetic variation: a multiple matrix regression approach for quantifying geographic and ecological isolation. Evolution 67:3403-3411 PubMed doi:10.1111/evo.12134

Wang IJ, Bradburg GS (2014) Isolation by environment. Mol Ecol 23:5649-5662 PubMed doi:10.1111/mec.12938

Wei K, Wood AR, Gardner JPA (2013) Seascape genetics of the New Zealand greenshell mussel: sea surface temperature explains macrogeographic scale genetic variation. Mar Ecol Prog Ser 477:107-121 doi:10.3354/meps10158

Weir BS, Cockerham CC (1984) Estimating F-statistics for the analysis of population structure. Evolution 38:1358-1370 PubMed

Wieters EA, Kaplan DM, Navarrete SA, Sotomayor A, Largier J, Nielsen KJ, Véliz F (2003) Alongshore and temporal variability in chlorophyll a concentration in Chilean nearshore waters. Mar Ecol Prog Ser 249:93-105 doi:10.3354/meps249093

Wieters EA, Broitman BR, Branch GM (2009) Benthic community structure and spatiotemporal thermal regimes in two upwelling ecosystems: comparisons between South Africa and Chile. Limnol Oceanogr 54:1060-1072 doi:10.4319/lo.2009.54.4.1060

Wright S (1943) Isolation by distance. Genetics 28:114-138 PubMed

Zakas C, Binford J, Navarrete SA, Wares JP (2009) Restricted gene flow in Chilean barnacles reflects an oceanographic and biogeographic transition zone. Mar Ecol Prog Ser 394:165-177 doi:10.3354/meps08265 
862 Table 1. Among-site genetic differentiation of Notochthamalus scabrosus at 7

863 microsatellite loci. Analyses were done with (A) the original database and (B) the database 864 corrected for null alleles. Values of $\theta_{\mathrm{ST}}$ are above the diagonal and $D_{\mathrm{EST}}$ values are below 865 the diagonal. CBaj: Carrizal Bajo, Apol: Apolillado, Temb: Temblador, Guan:

866 Guanaqueros, PTal: Punta Talca, LMol: Los Molles, Cura: Curaumilla, ECIM: Estación 867 Costera de Investigaciones Marinas (Las Cruces), Pich: Pichilemu (see Fig. 1). Shaded 868 boxes indicate values significant at the nominal level $(\mathrm{p}<0.05)$. Values in bold indicate 869 significant values after false discovery rate correction

\begin{tabular}{ccccccccccc}
\hline A & CBaj & Apol & Temb & Guan & PTal & LMol & Mont & Cura & ECIM & Pich \\
\hline \hline CBaj & - & 0.007 & $\mathbf{0 . 0 1 3}$ & $\mathbf{0 . 0 1 1}$ & $\mathbf{0 . 0 0 9}$ & $\mathbf{0 . 0 2 2}$ & $\mathbf{0 . 0 2 5}$ & $\mathbf{0 . 0 2 3}$ & $\mathbf{0 . 0 2 3}$ & $\mathbf{0 . 0 2 0}$ \\
\hline \hline Apol & 0.039 & - & 0.005 & 0.001 & 0.005 & $\mathbf{0 . 0 1 6}$ & $\mathbf{0 . 0 2 1}$ & $\mathbf{0 . 0 1 9}$ & $\mathbf{0 . 0 1 7}$ & $\mathbf{0 . 0 1 2}$ \\
\hline \hline Temb & $\mathbf{0 . 0 6 5}$ & 0.028 & - & 0.000 & 0.004 & $\mathbf{0 . 0 2 0}$ & $\mathbf{0 . 0 0 9}$ & $\mathbf{0 . 0 2 7}$ & $\mathbf{0 . 0 1 5}$ & 0.000 \\
\hline \hline Guan & $\mathbf{0 . 0 5 3}$ & 0.009 & 0.004 & - & -0.005 & $\mathbf{0 . 0 1 0}$ & 0.005 & 0.008 & $\mathbf{0 . 0 0 8}$ & 0.004 \\
\hline \hline PTal & 0.043 & 0.031 & 0.023 & -0.024 & - & 0.008 & 0.007 & 0.007 & 0.005 & -0.001 \\
\hline \hline LMol & $\mathbf{0 . 0 9 9}$ & $\mathbf{0 . 0 7 9}$ & $\mathbf{0 . 0 9 1}$ & 0.043 & 0.031 & - & $\mathbf{0 . 0 0 9}$ & 0.002 & $\mathbf{0 . 0 0 9}$ & 0.005 \\
\hline \hline Mont & $\mathbf{0 . 1 0 5}$ & $\mathbf{0 . 0 9 5}$ & 0.038 & 0.020 & 0.024 & 0.036 & - & 0.004 & -0.004 & -0.002 \\
\hline \hline Cura & $\mathbf{0 . 1 0 3}$ & $\mathbf{0 . 0 9 1}$ & $\mathbf{0 . 1 2 6}$ & 0.030 & 0.023 & 0.009 & 0.017 & - & 0.003 & $\mathbf{0 . 0 0 9}$ \\
\hline \hline ECIM & $\mathbf{0 . 0 9 0}$ & $\mathbf{0 . 0 7 1}$ & $\mathbf{0 . 0 5 9}$ & 0.027 & 0.012 & 0.035 & -0.013 & 0.015 & - & -0.002 \\
\hline \hline Pich & $\mathbf{0 . 0 8 6}$ & $\mathbf{0 . 0 5 7}$ & 0.001 & 0.015 & -0.004 & 0.024 & -0.008 & 0.038 & -0.005 & - \\
\hline & & & & & & & & & & \\
\hline B & CBaj & Apol & Temb & Guan & PTal & LMol & Mont & Cura & ECIM & Pich \\
\hline \hline CBaj & - & 0.004 & $\mathbf{0 . 0 1 0}$ & 0.006 & 0.011 & $\mathbf{0 . 0 1 6}$ & $\mathbf{0 . 0 2 0}$ & $\mathbf{0 . 0 2 3}$ & $\mathbf{0 . 0 1 8}$ & $\mathbf{0 . 0 1 9}$ \\
\hline \hline Apol & 0.013 & - & 0.007 & 0.001 & 0.004 & 0.008 & $\mathbf{0 . 0 1 5}$ & $\mathbf{0 . 0 1 3}$ & $\mathbf{0 . 0 1 2}$ & $\mathbf{0 . 0 1 0}$ \\
\hline \hline Temb & 0.037 & 0.013 & - & 0.003 & 0.009 & $\mathbf{0 . 0 1 3}$ & 0.005 & $\mathbf{0 . 0 2 4}$ & 0.008 & 0.001 \\
\hline \hline Guan & 0.027 & $-0,009$ & -0.012 & - & 0.007 & 0.008 & 0.007 & 0.008 & $\mathbf{0 . 0 1 0}$ & 0.007 \\
\hline \hline PTal & 0.010 & -0.002 & -0.008 & -0.045 & - & 0.011 & $\mathbf{0 . 0 1 6}$ & $\mathbf{0 . 0 1 5}$ & 0.010 & 0.010 \\
\hline \hline LMol & 0.073 & 0.054 & 0.060 & 0.016 & 0.007 & - & 0.007 & 0.004 & 0.009 & 0.005 \\
\hline \hline Mont & 0.079 & 0.070 & 0.018 & 0.005 & 0.001 & 0.019 & - & 0.007 & 0.000 & 0.000 \\
\hline \hline Cura & 0.084 & 0.063 & 0.105 & 0.010 & 0.002 & -0.006 & 0.005 & - & 0.007 & 0.006 \\
\hline \hline ECIM & 0.068 & 0.052 & $\mathbf{0 . 0 3 9}$ & 0.016 & -0.009 & 0.019 & -0.022 & 0.001 & - & 0.000 \\
\hline \hline Pich & 0.061 & 0.035 & -0.010 & 0.003 & -0.026 & 0.003 & -0.020 & 0.023 & -0.021 & - \\
\hline
\end{tabular}

872 Table 2. Results of generalized linear modeling (GLM) analyses employed to identify the 873 best fit model for 5 variables explaining genetic diversity of Notochthamalus scabrosus.

874 AIC: Akaike's information criterion, Ar: allelic richness; Gd: gene diversity;

875 CHLA1(CHLA2): PC1 (PC2) of chlorophyll $a$ concentration; SST1 (SST2): PC1 (PC2) of 876 sea surface temperature; Cov: adult cover of $N$. scabrosus ( $\log _{10}$ transformed); Lon:

877 longitude, VarExp: variance explained. Values in bold are significant $(\mathrm{p}<0.05)$ 


\begin{tabular}{|c|c|c|c|c|c|c|}
\hline \multicolumn{4}{|l|}{ GLM test } & \multicolumn{2}{|c|}{ Test of effects } & \multirow{2}{*}{$\begin{array}{l}\text { VarExp } \\
(\%) \\
\end{array}$} \\
\hline Initial full model & Best fit models & $\mathrm{p}$ & AIC & Variable & $\mathrm{p}$ & \\
\hline $\mathrm{Ar} \sim \mathrm{CHLA} 1+\mathrm{CHLA} 2$ & Ar $\sim$ CHLA2+Cov+Lon & 0.568 & 19.38 & CHLA2 & 0.044 & 48.61 \\
\hline \multirow[t]{5}{*}{ +SST1+Cov+Lon } & & & & Cov & 0.123 & 15.39 \\
\hline & & & & Lon & 0.436 & 3.74 \\
\hline & $\mathrm{Ar} \sim \mathrm{CHLA} 2+\mathrm{Cov}$ & $<0.001$ & 18.47 & CHLA2 & $\mathbf{0 . 0 4 3}$ & 48.61 \\
\hline & & & & Cov & 0.127 & 15.39 \\
\hline & $\mathrm{Ar} \sim \mathrm{CHLA} 2$ & $<0.001$ & 20.03 & CHLA2 & $\mathbf{0 . 0 2 5}$ & 48.61 \\
\hline Gd CHLA1+CHLA2 & Gd CHLA1+CHLA2+Cov & $<0.001$ & $\begin{array}{l}- \\
57.61 \\
\end{array}$ & CHLA1 & 0.125 & 2.96 \\
\hline \multirow[t]{5}{*}{ +SST1+Cov+Lon } & & & & CHLA2 & 0.010 & 67.80 \\
\hline & & & & Cov & 0.369 & 3.97 \\
\hline & $\mathrm{Gd} \sim \mathrm{CHLA} 1+\mathrm{CHLA} 2$ & $<0.001$ & $\begin{array}{l}- \\
58.15\end{array}$ & CHLA1 & 0.173 & 2.96 \\
\hline & & & & CHLA2 & 0.005 & 67.80 \\
\hline & Gd CHLA2 & $<0.001$ & $\begin{array}{l}- \\
57.31 \\
\end{array}$ & CHLA2 & 0.008 & 67.80 \\
\hline
\end{tabular}

878

883 Table 4. Results of multiple regression on distance matrices (MRDM). Abbreviations as in

884 Table 2; values in bold are significant $(p<0.05)$

\begin{tabular}{lllllll}
\hline MRDM full model & & Coef & p & $\mathrm{R}^{2}$ & $F$ & $\mathrm{p}$ \\
\hline \hline$\theta_{\text {ST }} \sim$ & & & & & & \\
CHLA1+CHLA2+SST1+SST2 & Int & 0.007 & 0.512 & 0.55 & 6.445 & $\mathbf{0 . 0 0 8}$ \\
\hline \hline +Rec+Cov+Lon & CHLA1 & -0.006 & 0.534 & & & \\
\hline \hline & CHLA2 & -0.001 & 0.953 & & \\
\hline \hline & SST1 & -0.041 & 0.629 & & \\
\hline \hline & SST2 & 0.024 & $\mathbf{0 . 0 0 2}$ & & \\
\hline \hline
\end{tabular}

Table 3. Results of the stepAIC analyses employed to identify the best fit model for 5 variables explaining genetic diversity of Notochthamalus scabrosus. Abbreviations as in Table 2

\begin{tabular}{lll}
\hline \multicolumn{1}{l}{ stepAIC test } & \\
\hline Initial full model & Best fit model & AIC \\
\hline \hline Ar CHLA1+CHLA2 & Ar CHLA2+Cov & 22.69 \\
\hline +SST1+Cov+Lon & & \\
\hline \hline Gd CHLA1+CHLA2 & Gd CHLA1+CHLA2 & -54.74 \\
\hline +SST1+Cov+Lon & & \\
\hline
\end{tabular}

882 


\begin{tabular}{lllllll}
\hline & Rec & 0.004 & 0.401 & & \\
\hline \hline & Cov & -0.000 & $\mathbf{0 . 0 3 6}$ & & \\
\hline \hline & Lon & -0.014 & 0.084 & & \\
\hline \hline$D_{\text {EST }}$ CHLA1+CHLA2+SST1+SST2 & Int & 0.007 & 0.508 & 0.55 & 6.445 & $\mathbf{0 . 0 0 7}$ \\
\hline \hline+ Rec+Cov+Lon & CHLA1 & -0.006 & 0.527 & & & \\
\hline \hline & CHLA2 & -0.001 & 0.951 & & \\
\hline \hline & SST1 & -0.041 & 0.618 & & \\
\hline \hline & SST2 & 0.024 & $\mathbf{0 . 0 0 2}$ & & \\
\hline \hline & Rec & 0.004 & 0.405 & & \\
\hline \hline & Cov & -0.000 & $\mathbf{0 . 0 3 5}$ & \\
\hline \hline
\end{tabular}

885

886

887

888

889

890

891

892

893

894

895

896

897

898

899

900

901

902

Fig. 1. Central-northern coast of Chile, showing the 10 sampling sites and weekly averages of sea surface temperature (SST) for nearshore areas. ECIM: Estación Costera de Investigaciones Marinas

Fig. 2. Principal coordinates analysis calculated by $\theta_{\mathrm{ST}}$ (top) and $D_{\mathrm{EST}}$ (bottom) values of 10 sites studied. For $\theta_{\mathrm{ST}}$ and $D_{\mathrm{EST}}$ indices, the first 2 axes explain 87.62 and $87.88 \%$ of the total variation, respectively. Site abbreviations as in Table 1

Fig. 3. STRUCTURE assignment of individual Notochthamalus scabrosus across all sites into clusters for $k$ between 2 and 4. Colors indicate percentage contribution of individuals to assigned clusters ( $y$-axis), individuals are represented by each line ( $x$-axis); black lines separate sites from which individuals were collected. Site abbreviations as in Table 1

Fig. 4. Results for the linear regressions among 8 predictive and 2 dependent variables. Ar: allelic richness, Gd: gene diversity; CHLA1 (CHLA2): PC1 (PC2) of chlorophyll $a$ concentration; SST1 (SST2): PC1 (PC2) of sea surface temperature; Rec: arrival rate of larval Notochthamalus scabrosus ( $\log _{10}$ transformed); Cov: adult cover of $N$. scabrosus ( $\log _{10}$ transformed); Lat: latitude; Lon: longitude. Star in panel f represents the Estación Costera de Investigaciones Marinas (ECIM) site 


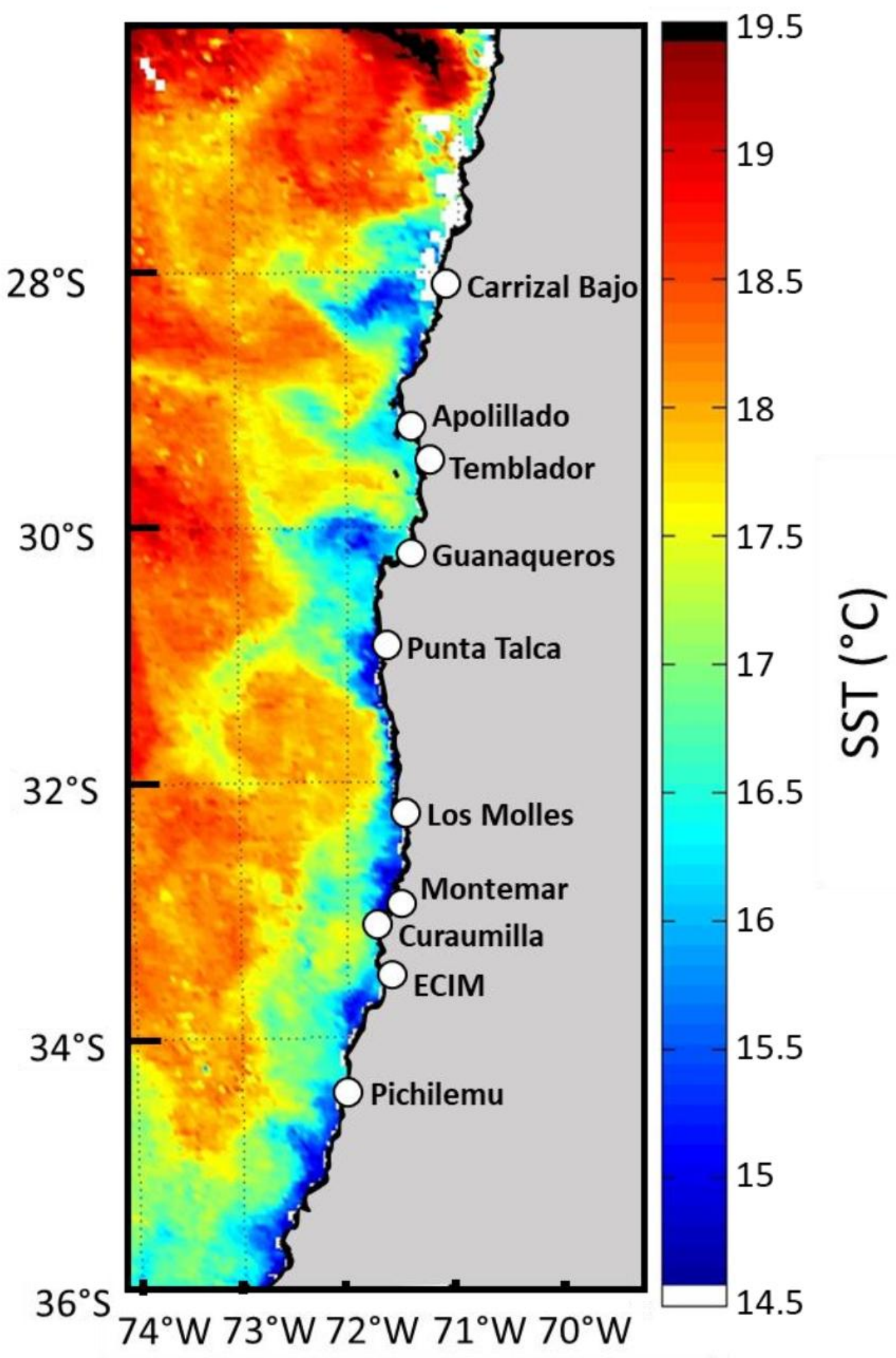




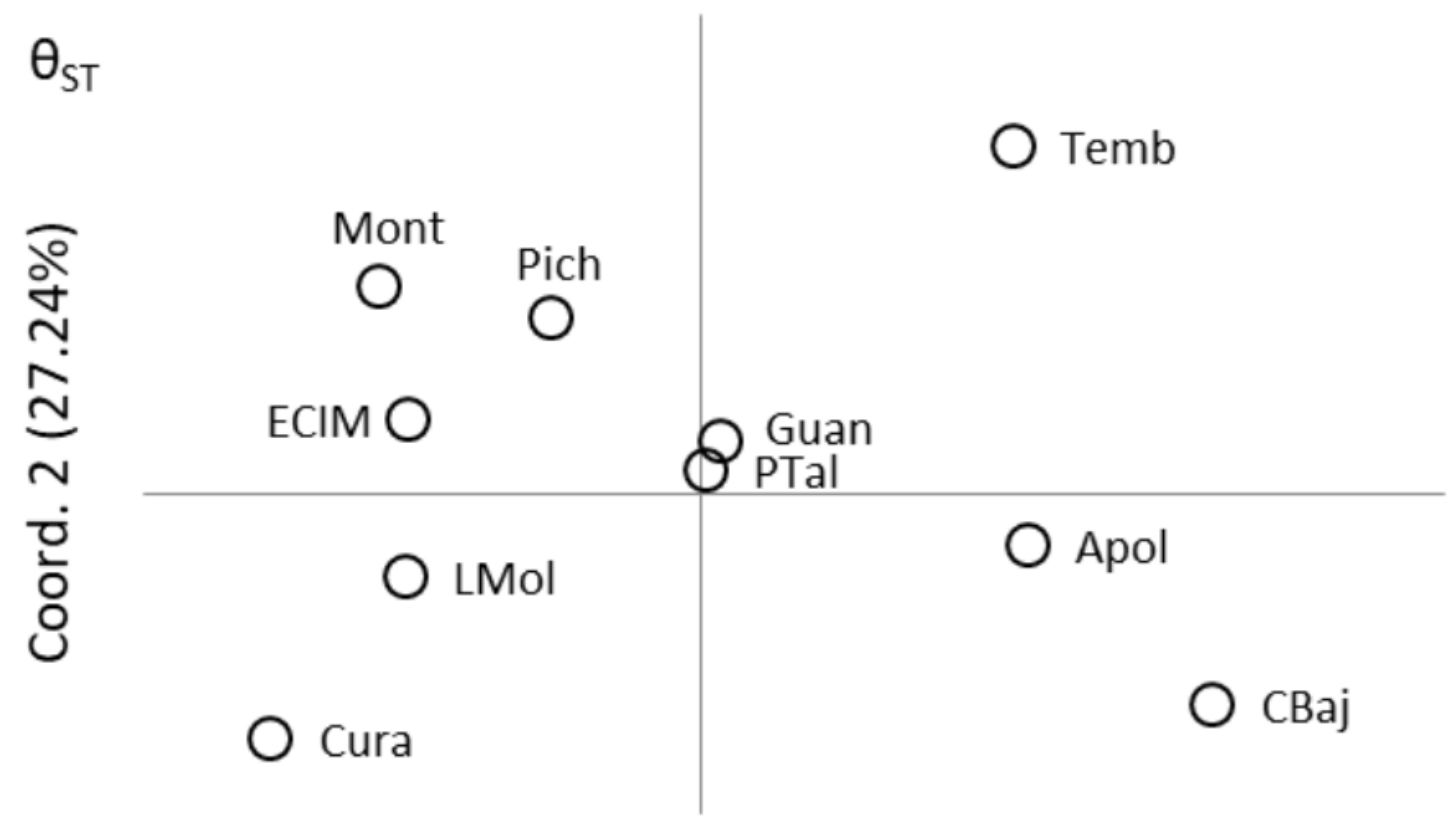

Coord. 1 (60.38\%)

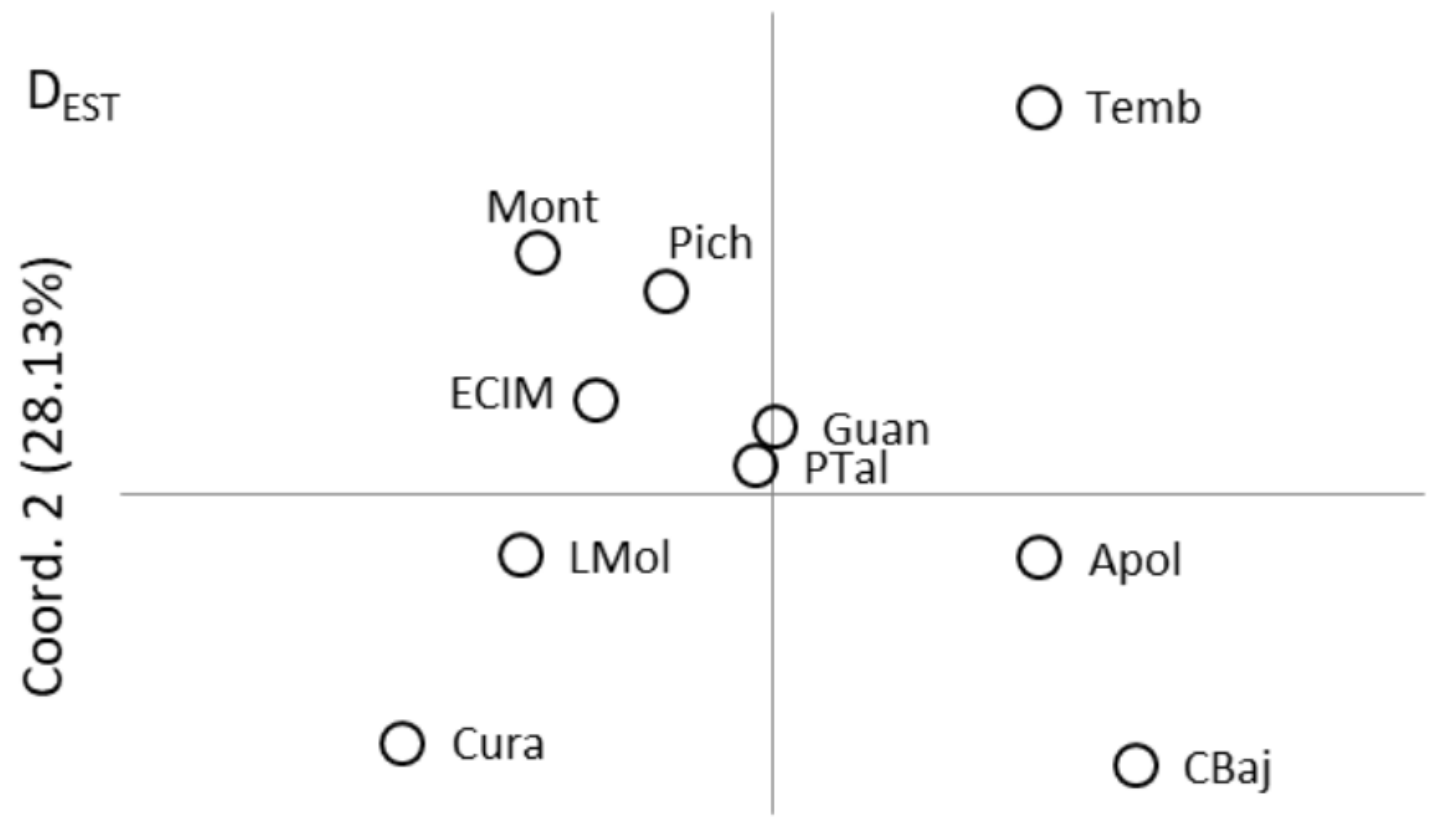



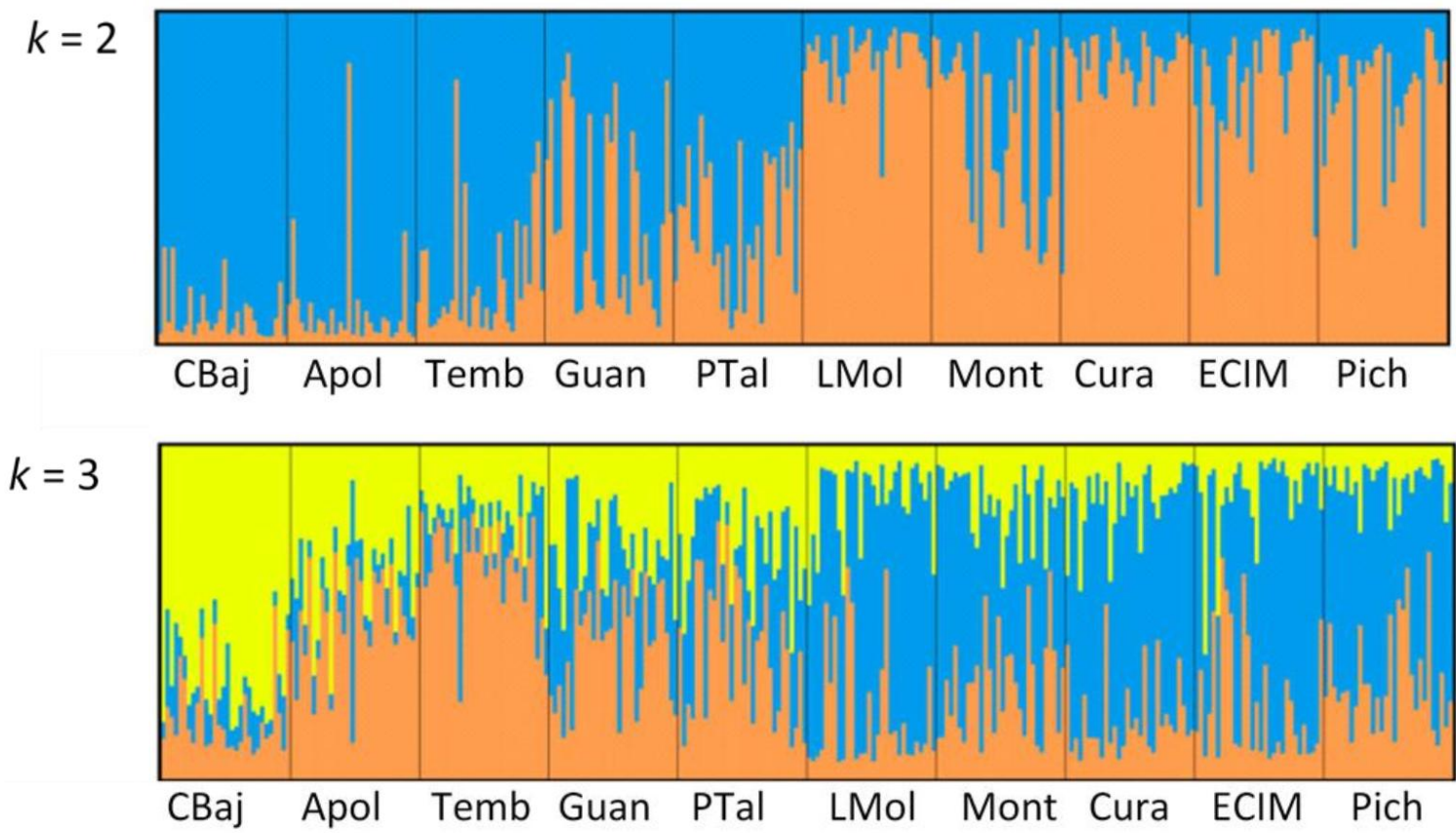

$$
k=4
$$

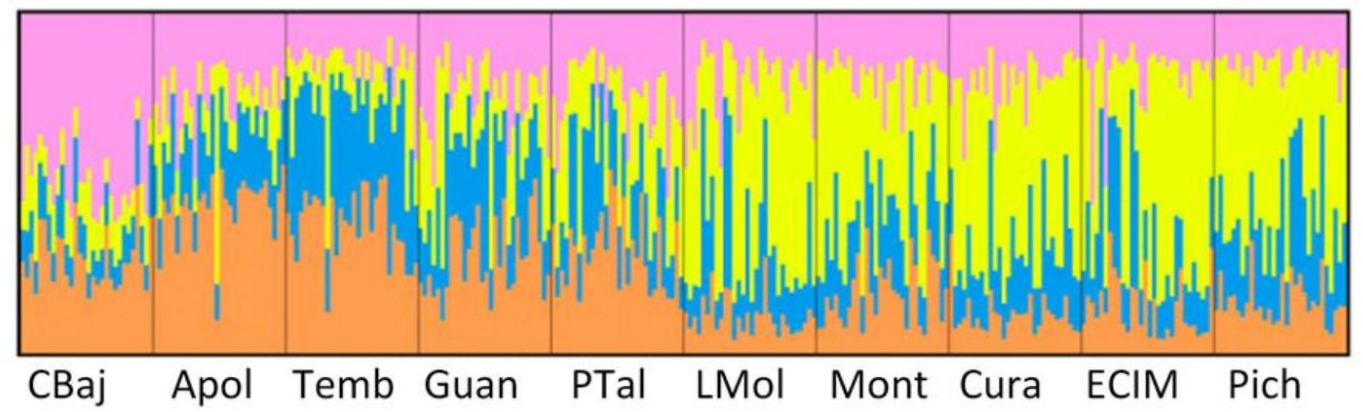



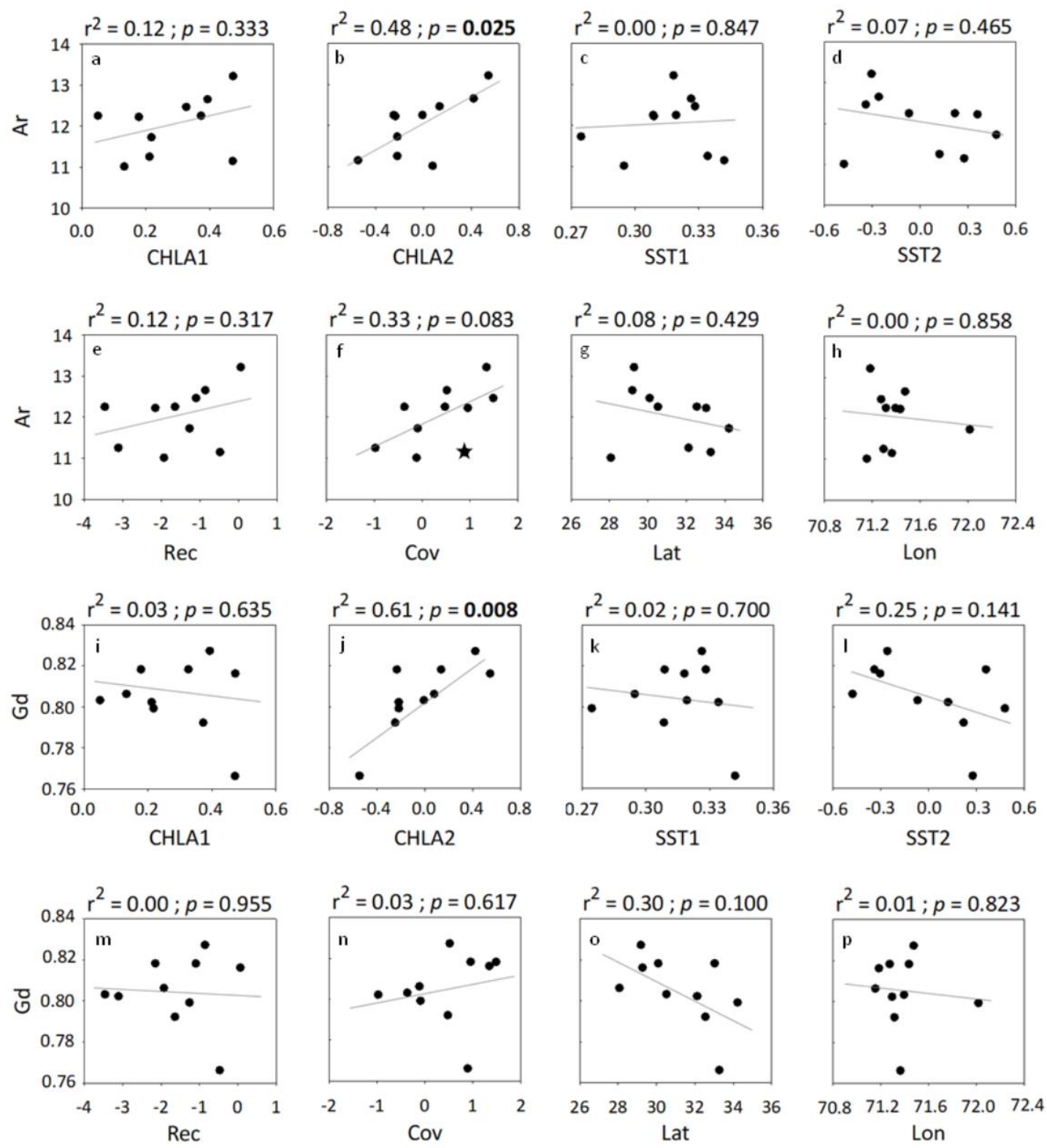

909

910 

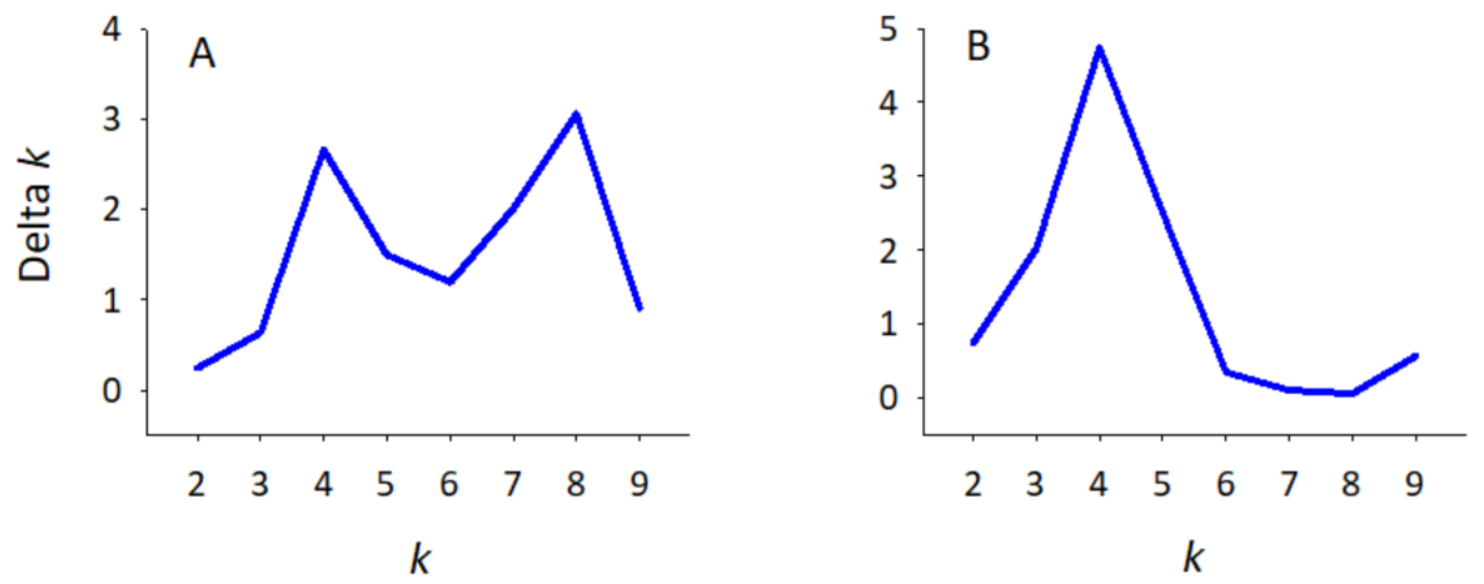

911

Figure S1

913 


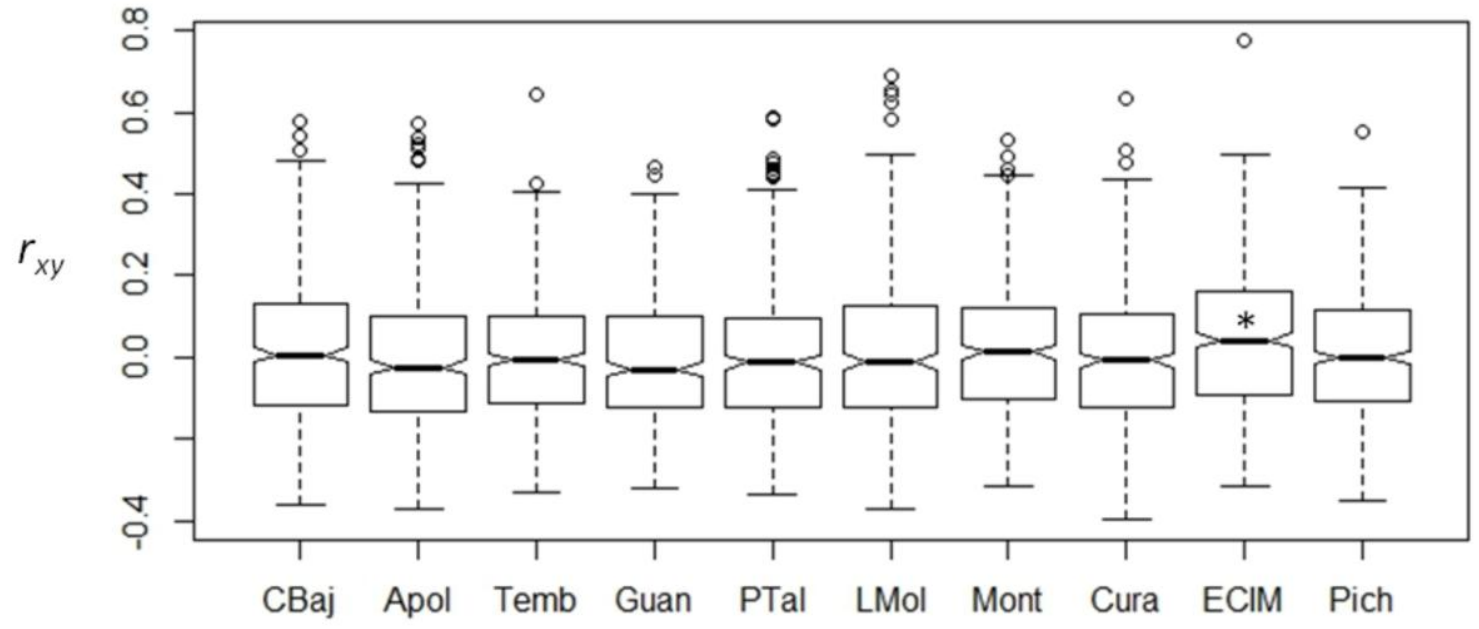

915 Figure S2 